\title{
THE HEPATIC DAMAGE OF THE CEREBRAL ORIGIN
}

\author{
Miyoshi URABE and Makoto KIKUCHI \\ Department of Surgery, School of Medicine, \\ University of Kanazawa
}

\section{INTRODUCTION}

The liver occupies the largest volume among the parenchymatous organs and plays an important role in the metabolism. Correlation between the liver and the central nervous system has long been noticed from the clinical aspect and from the experimental view point. Regarding the so-called hepatocerebral disease, Layden (1890) has first described intoxication of the central nervous system of the hepatic origin. In 1912 Wilson $\left.{ }^{4 \overline{ }}\right)$ reported a case of the disease where the liver cirrhosis and degeneration of the lenticular nuclei developed simultaneously. In 1920 Spielmyer ${ }^{38}$ ) made more precise pathological examinations on Wilson's disease and explained that the liver cirrhosis in this disease had a causative relation to degeneration of the central nervous system. Since then, the subject on relation between the liver and the central nervous system has been discussed from the patho-histological standpoint.

The genesis of the so-called hepatocerebral disease has been explained as follows. (1) The first explanation indicated that the liver disease occurred primarily and it caused changes of the brain secondarily. Wilson described that a kind of noxa was produced from the disfunctioned liver, resulting in changes of the lenticular nuclei. Lüthy ${ }^{27)}$ et al also said that the poisons produced by metabolic disorder of the liver caused degeneration in the central nervous system. (2) The second explanation indicated that the cerebral changes occurred primarily and changes of the liver followed secondarily. Boenheim ${ }^{3}$ ) said the liver cirrhosis was caused by disorder of the subthalamic enter. Ricker ${ }^{341}$ stated the same opinion. (3) The third explanation indicated that damages of the liver as well as the brain were caused secondarily by disorders of the organs else, by disorder of general metabolism or by the extracorporeal toxins. Rössle et $\mathrm{al}^{26,351}$ related that metabolic disorders produced the noxa both in the tissue of the liver and in the extrapyramidal system.

The experimental studies regarding relation between the central nervous system and the liver were performed mostly by examination of the cerebral changes at the

$$
-51-
$$


time of the hepatic damage. There was relatively a few study on the hepatic changes at the time of the cerebral damage. In the experiments of the rabbit, Yoshino $^{46}$ ) et al observed the marked hepatic lesion in the cases where the hypothalamus was destroyed. Usami et al ${ }^{42)}$ also observed a distinct hepatic damage in the case of electrical coagulation of the hypothalamus, "the striate body and the mamillary body of the rabbit. Akiyama ${ }^{2)}$ reported that electrocoagulation or electric stimulation of the caudate nuclei, the globus pallidus and the putamen of the rabbits caused disturbance of the hepatic function. Thus there was no definite opinion regarding foci of the brain which caused selectively the hepatic disturbances.

The present authors have performed following four examinations in order to study the central innervation of the liver. Firstly, we examined the hepatic function in the clinical cases of the brain tumor and the brain trauma and observed relation between the site of the cerebral damage and disturbance of the hepatic function. Secondly, we performed histological examination of the liver tissue in the autopsy cases died of the brain disease, mostly the brain tumor. Thirdly we performed histological and histochemical examinations of the liver of the rabbit where the brain tumor was experimentally produced. Fourthly changes of the hepatic circulation were observed subsequent to an electrical stimulation of the various regions of the brain of the mongrel dog.

\section{Methods}

1. Method for examination in the clinical case.

Clinical cases were consisted of 34 brain tumors and 12 brain traumas who were admitted and operated upon, in the 1st Surgical Department, School of Medicine, University of Kanazawa, for 3 years from 1959 to 1961. In these patients, the hepatic functional tests were carried out regarding following 11 items: (1) Serum proteins ${ }^{20)}(\mathrm{g} / \mathrm{dl})$, (2) Meulengracht's jaundice index ${ }^{20)}$, (3) Urobilinogen in urine ${ }^{20)}$, (4) Serum cobalt reaction ${ }^{21)}$, (5) Serum cadmium reaction ${ }^{20)}$, (6) Takata's reaction ${ }^{19)}$, (7) CCF-test ${ }^{17}$ ), (8) Lugol reaction ${ }^{40)}$, (9) Clearance-test of BSP $^{36)}(\%)$, (10) Blood sugar (mg/dl) and (11) Serum cholesterol (mg/dl).

2. Method for examination in the autopsy case.

Autopsy cases were consisted of 125 brain tumors and the other diseases which were picked out of the tremendous sources in the pathological departments of Kanazawa and Tokyo Universities for last 10 years. The hepatic lesions of these materials were examined by the histological and histochemical methods. The cases assumed to have a serious generalized disorder or to have the marked post-mortem changes, were skipped out of the materials. According to degree, the histological changes of the hepatic lesions were classified into four stages: intense, moderate, slight, and normal ones. In the intense changes of the liver, the hepatocellular necrosis was mentioned as an acute change and the liver cirrhosis as a progressive 
chronic change (Fig. 1,2). The marked fatty liver and the hepatocellular degeneration were mentioned as the moderate changes of the liver (Fig. 3). The trifling ones of all the above findings were mentioned as the slight changes (Fig. 4).

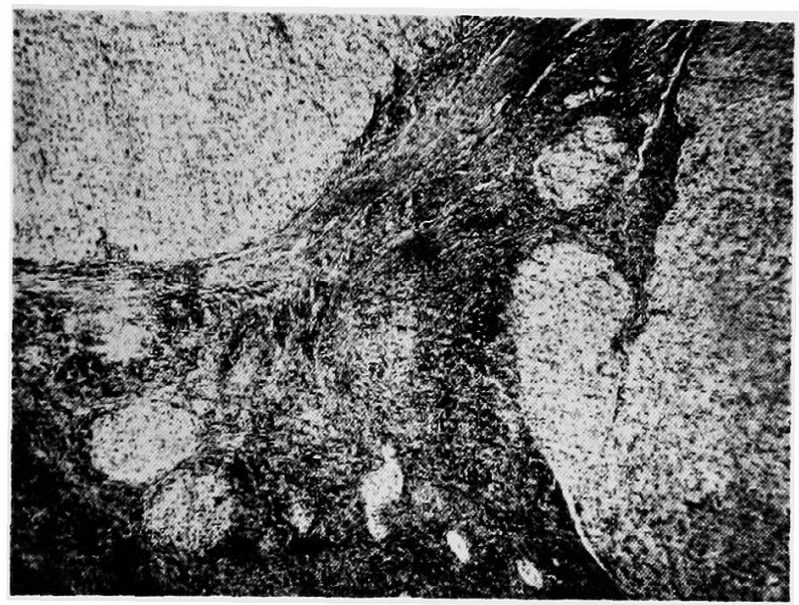

Fig. 1. Severe histological changes in the case of softening of the basal ganglia. (H.O. 23 years old, female, H-E staining $\times 50$ )

The pseudolobulus was formed by the wide stroma with a remarkable proliferation of the fibrous tissue. The liver cells and the nuclei appeared inequally. The fatty degeneration was also seen.

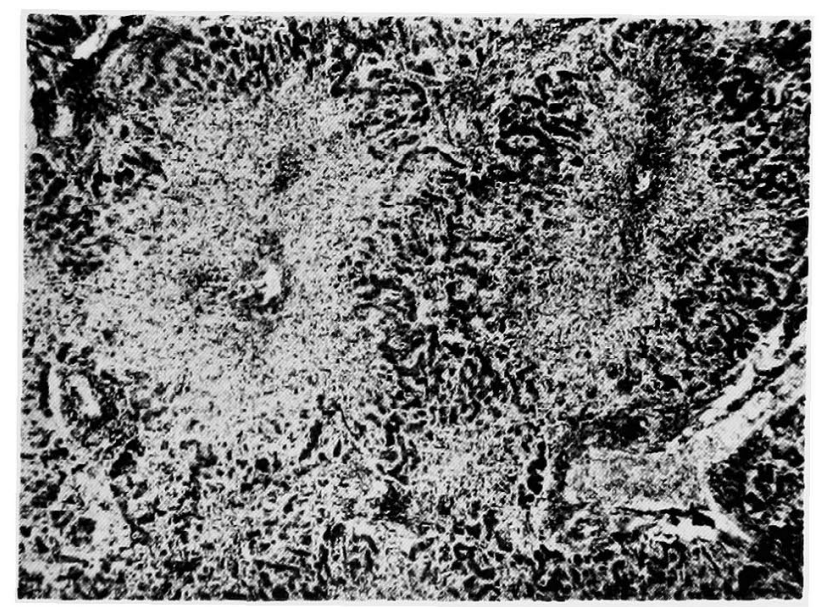

Fig. 2. Severe hepatic damage in the case of the hypophyseal tumor. (W.A. 13 years old, male, H-E staining $\times 50$ )

Diffuse severe degeneration and necrosis of the liver cells were seen around the lobules. Fatty granules were seen in a small amount. 


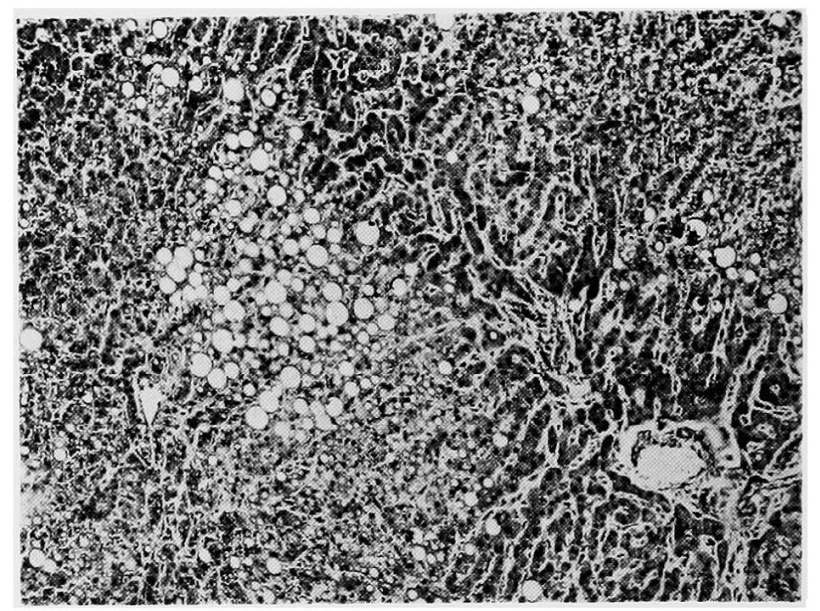

Fig. 3. Moderate hepatic damage in the case of the tumor of the basal ganglia. (M.U. 33 years old, male, H-E staining $\times 100$ )

Conspicuous fatty granules were seen over the most part of the lobules. The structure of the liver cell column and the sinusoid were vague. Histological pattern of the marked fatty liver was seen.

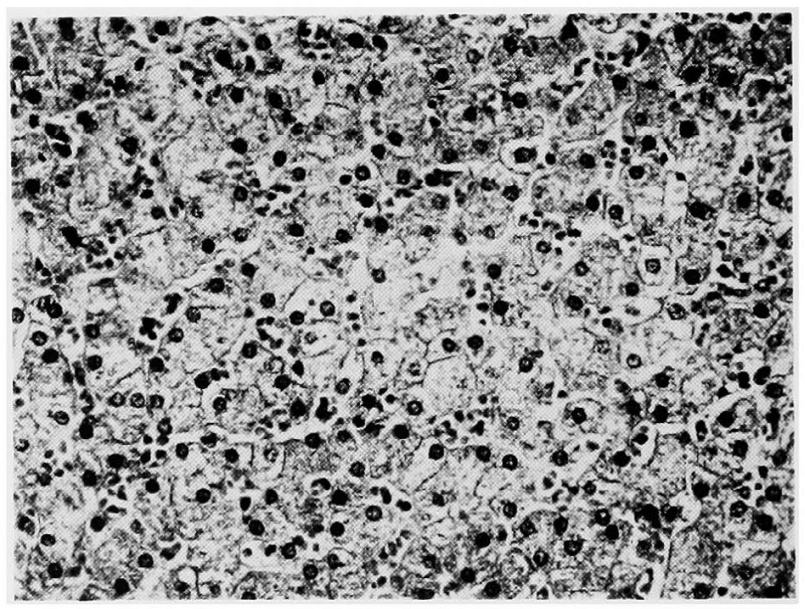

Fig. 4. Slight hepatic damage in the case of the infratentorial tumor. $(N . A .6$ years old, male, H-E staining $\times 300$ )

Vacuole formation in the protoplasm and swelling of the liver cells, and conspicuous abnormal granules were seen. Achromatization and pyknosis of the nuclei were much present.

3. Method for studies of the experimentally produced brain tumor of the rabbit.

71 male adult rabbits weighing 2.0-3.0 kg were used. Under ether anesthesia, the animal was fixed to the stereotaxic apparatus, craniotomy was carried out, and 
Brown-Pearce cancer ${ }^{1,22,23)}$ about $0.5 \mathrm{~mm}$ in diameter was inserted into the aimed portion of the brain. The survival time of the animals was about 2 weeks after transplantation into the cerebellar portion, and about 3 weeks after transplantation into the other portions of the brain. Anorexia and anemia appeared 2 or 3 days before the death. When these symptoms appeared, the animals were sacrificed, and the liver, the kidney, the stomach, the intestine, the pancreas and the brain were taken out and fixed in 10 percent formalin or cold aceton. The sections were made and stained by hematoxylin-eosin. In addition to this procedure, sudan $\mathrm{III}^{24)}$, $\mathrm{PAS}^{25)}$, alkaline and acid phosphatase (modified Gomori's method) ${ }^{1+)}$ and pyroninmethylgreen $^{37}$ ) stainings were employed. Several frontal sections were made on the brain and the site of the tumor and its extent were examined macroscopically. Swelling or atrophy of the liver cells, degeneration of the cytoplasm, achromatization and karyolysis of the nucleus, abnormal findings of the stroma were observed as the microscopical changes of the liver in hematoxylin-eosin staining. These histological findings classified into 5 stages from the one similar to the contrast group ( - ) to the most marked one ( $\mathrm{l})$. The histochemical changes were classified into 3 stages: the intensified one more than the contrast group was marked as $\uparrow$, the weakened one as $\downarrow$ and almost the normal one as $\fallingdotseq$. The summarized findings, including both histological and histochemical changes were classified into 5 stages: the severe hepatic damage was marked as $\#,+$. the slight one as + , and almost the normal one as - (Fig. 5, 6).

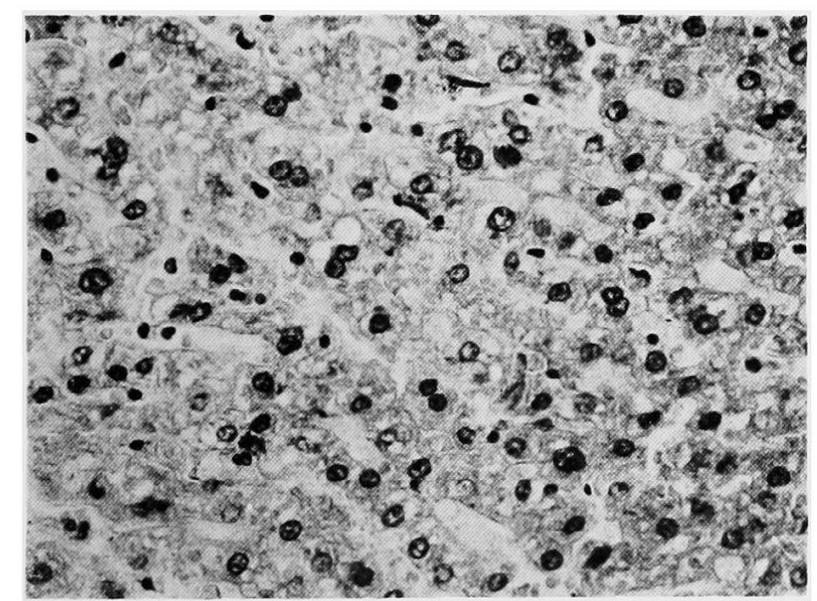

Fig. 5. Histological findings of the liver in the case of the experimental tumor of the caudate nucleus. (Rabbit No. 34, H-E staining $\times 300$ )

Inequality of staining, vacuole formation and abnormal granules were seen in the cytoplasm of the liver cell. Achromatization, necrosis and pyknosis of the nuclei were markedly seen. 


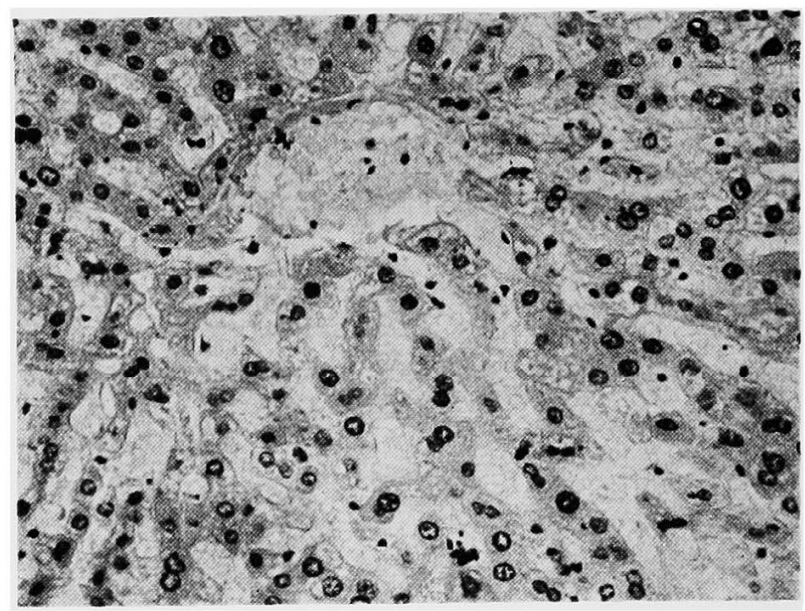

Fig. 6. Histological findings of the liver in the case of the cortex tumor. (Rabbit No. 14, H-E staining $\times 300$ )

Dilatation of the sinusoids was marked. Disse's space was filled with the edema fluid. Thereforc, the liver cell column was compressed, resulting in the marked atrophy.

4. Method for examination of the hepatic blood flow at the time of electrocoagulation of the brain of dog.

41 mongrel dogs weighing $8-12 \mathrm{~kg}$ were used. Under the anesthesia of the intraperitoneal injection of $50 \mathrm{mg} / \mathrm{kg}$ of Thiopental sodium, canulations were done in the femoral artery and vein for measuring the blood pressure, injecting $\mathrm{Au}^{198}$ colloid and taking the blood samples. Then the animal was fixed on the stereotaxic apparatus and craniotomized around the aimed portion. The electrode was inserted into the brain tissues and electro-coagulation was carried out with the high frequent current for $15-30 \mathrm{sec}$. The hepatic blood flow was measured before, 1 hour, 3 hours, 5 hours after, coagulation respectively.

The hepatic blood flow was calculated from a clearance curve $\mathrm{Au}^{198}$ colloid in the blood ${ }^{43)}$. After $50 \mu \mathrm{c}$ of $\mathrm{Au}^{198}$ colloid and Evans blue were injected simultaneously into the femoral vein, $1 \mathrm{cc}$ of the blood was taken from the contralateral artery every one minute for 10 minutes. Circulating blood volume was measured by the Evans blue clearance method. The activity of the isotope in the blood was measured by the scintillation counter. And its half-value time in the blood was known. The hepatic blood flow was calculated by the following formula.

$$
\begin{gathered}
K=\frac{\log _{e} 2}{T^{1 / 2}}=\frac{0.693}{T^{1 / 2}} \\
\operatorname{LBF}(\mathrm{ml} / \mathrm{min})=\mathrm{CBV}^{\mathrm{ml}} \times K^{-1} \mathrm{~min}
\end{gathered}
$$

LBF: liver blood flow

CBV: circulating blood volume 
$K$ : $\quad$ clearance index

$T^{1 / 2}$ : half-value time (half time of disappearance)

\section{REsults}

1. Result of examination in the clinical case.

The site of the lesion in the brain tumor and the brain trauma cases was ascertained by the operation. The cases were classified into four groups according to the site of the lesion: the group of the basal ganglia and the diencephalon, the group of the cortex and the subcortical white matter, the group of the hypophyseal region and the group of the infratentorial region (Fig. 7). The hepatic function of each group was examined (Fig. 8).

(1) Liver function in the group of the basal ganglia and the diencephalon (Tab. 1, Fig. 9, 10):

Disorders of the liver function were seen in 10 ( 83.8 percent) of 12 cases where the cerebral lesions were situated in the basal ganglia, consisting of the caudate nucleus, the globus pallidus, the putamen, the claustrum and the amygdaloid nucleus, and in the diencephalon consisting of the thalamus, the epithalamus, metathalamus and the hypothalamus. Among them, 8 cases ( 66.6 percent) showed intensive disorder of the liver function. Two cases showing no disturbance of the liver function were the craniopharyngiomas.
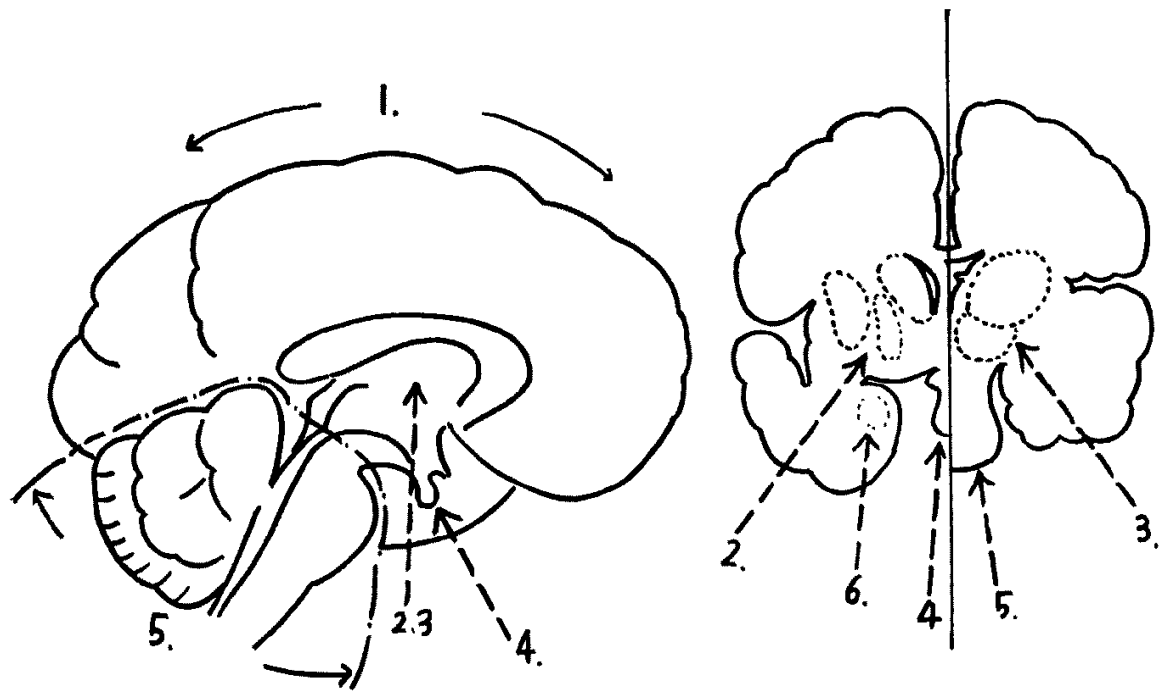

Fig. 7. Schematic illustration of the regions of the brain.

1. Cortex and subcortical white matter.

2. Caudate nucleus, globus pallidus and putamen.

3. Thalamus and hypothalamus.
4. Hypophyseal region.

5. Cerebellum, pons and medulla oblongata (infratentorial region).

6. Amygdaloid nucleus. 

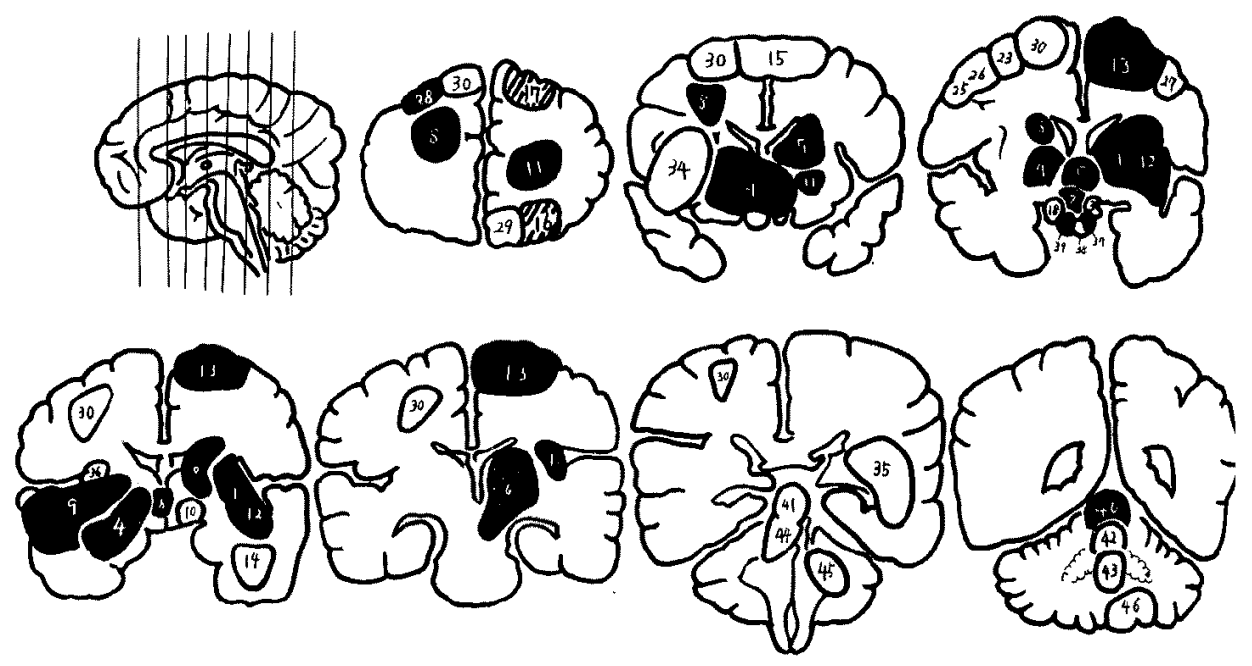

Fig. 8. The site of the brain tumors and the brain traumas where hapatic damages were shown (clinical cases).

- Intense disorder of the hepatic function.

- Moderate disorder of the hepatic function.

Almost no change in the hepatic function.

Table 1, Liver functions in 12 cases where the brain tumor or the

\begin{tabular}{|c|c|c|c|c|c|c|c|c|}
\hline Case No. & Patient & Sex & Age & Diagnosis & $\underset{\text { protein }}{\text { Serum }}$ & $\begin{array}{c}\text { Meulen- } \\
\text { gracht's } \\
\text { index }\end{array}$ & $\begin{array}{l}\text { Urobili- } \\
\text { nogen } \\
\text { in urine }\end{array}$ & $\begin{array}{c}\text { Serum } \\
\text { cobalt } \\
\text { reaction }\end{array}$ \\
\hline 1 & $\mathbf{H}$ & 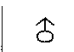 & 12 & Brain tumor & $8.2 \mathrm{~g} / \mathrm{dl}$ & 6 & $(+)$ & 3 \\
\hline 2 & $\mathbf{N}$ & 오 & 29 & Brain tumor & 8.0 & 4 & $(+)$ & $6(7)$ \\
\hline 3 & $\mathbf{S}$ & $\delta$ & 40 & Brain tumor & 7.0 & 6 & $(+)$ & $0(4)$ \\
\hline 4 & M & 9 & 26 & Brain tumor & 7.4 & 7 & $(+)$ & $6(7)$ \\
\hline 5 & $\mathrm{SA}$ & 우 & 13 & Brain tumor & 7.6 & 5 & $(+)$ & $0(3)$ \\
\hline 6 & $\mathrm{~K}$ & $\delta$ & 26 & Brain tumor & 7.2 & 6 & $(+)$ & $4(7)$ \\
\hline 7 & $\mathrm{Y}$ & $\$$ & 67 & Brain contusion & 6.2 & 6 & $(+)$ & $3(6)$ \\
\hline 8 & $\mathrm{~T}$ & $\hat{\delta}$ & 18 & Brain contusion & 8.2 & 4 & $(+)$ & $0(5)$ \\
\hline 9 & $\mathrm{SE}$ & 우 & 52 & Brain tumor & 6.8 & 5 & $(+)$ & $3(5)$ \\
\hline 10 & MI & 우 & 15 & Brain tumor & 7.0 & 4 & $(+)$ & $4(6)$ \\
\hline 11 & $\mathrm{MU}$ & 오 & 49 & Brain tumor & 7.0 & 6 & $(+)$ & $5(7)$ \\
\hline 12 & 0 & 오 & 12 & Brain tumor & 8.2 & 8 & $(+)$ & $7(8)$ \\
\hline
\end{tabular}




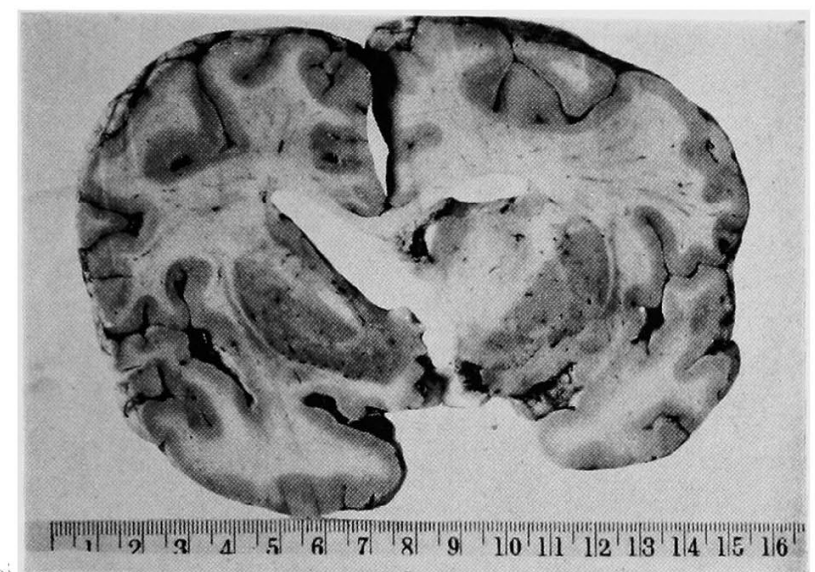

Fig. 9. Photograph of the tumor in the basal ganglia and the diencephalon. (Clinical case No. 6, Kaji, 26 years old, male, died after operation)

The striate body, especially the caudate nucleus was invaded by the tumor.

Hepatic functions showed severe disorder before operation: serum protein $7.2 \mathrm{~g} / \mathrm{dl}$, Meulengracht's index 6 , urobilinogen in urine $(+)$, serum cobalt reaction $4(7)$, serum cadmium reaction 8 , Lugol reaction $(+)$, Takata's reaction $(-)$, CCF-test $(+)$, BSP clearance $6.5 \%$, serum cholesterol $182 \mathrm{mg} / \mathrm{dl}$. Judgement of summarized functional disorders (卅).

brain trauma was in the basal ganglia and the diencephalon.

\begin{tabular}{|c|c|c|c|c|c|c|c|c|}
\hline $\begin{array}{l}\text { Serum } \\
\text { cadmium } \\
\text { reaction }\end{array}$ & $\begin{array}{l}\text { Lugol } \\
\text { reaction }\end{array}$ & $\begin{array}{l}\text { Takata's } \\
\text { reaction }\end{array}$ & $\begin{array}{l}\mathrm{CC} \\
\mathrm{te}\end{array}$ & $\begin{array}{l}\text { CF } \\
\text { st }\end{array}$ & $\begin{array}{c}\text { BSP } \\
\text { clearance }\end{array}$ & $\begin{array}{l}\text { Serum } \\
\text { cholesterol }\end{array}$ & $\begin{array}{l}\text { Blood } \\
\text { sugar ((in } \\
\text { hunger) }\end{array}$ & $\begin{array}{c}\text { Judge- } \\
\text { ment }\end{array}$ \\
\hline 8 & - & \pm+ & - & - & $5.0 \%, 2.0 \%$ & $162 \mathrm{mg} / \mathrm{dl}$ & $62 \mathrm{mg} / \mathrm{dl}$ & H \\
\hline 7 & + & $-\quad-$ & - & - & - & 199 & 70 & + \\
\hline 9 & - & $-\quad-$ & - & - & $3.5,2.0$ & 237 & 76 & - \\
\hline 6 & \# & $-\quad-$ & - & - & $4.0,2.0$ & - & 70 & H \\
\hline 10 & + & $-\quad \pm$ & + & - & - & - & 70 & H \\
\hline 8 & + & $-\quad-$ & + & - & $9.0,6.5$ & 182 & - & m \\
\hline 9 & H & $+\quad H$ & - & - & $5.0,2.5$ & 156 & 104 & m \\
\hline 10 & + & \pm+ & + & - & $2.5,0$ & - & 78 & $H$ \\
\hline 7 & - & $-\quad \pm$ & - & - & - & 144 & $\longrightarrow$ & + \\
\hline 7 & - & $-\quad-$ & - & - & $3.0,0$ & 121 & 76 & - \\
\hline 8 & + & $+H$ & + & H & $6.0,2.0$ & 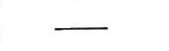 & 70 & $H$ \\
\hline 5 & H & $\pm \quad+$ & - & + & $4.0,0$ & 186 & 82 & H \\
\hline
\end{tabular}




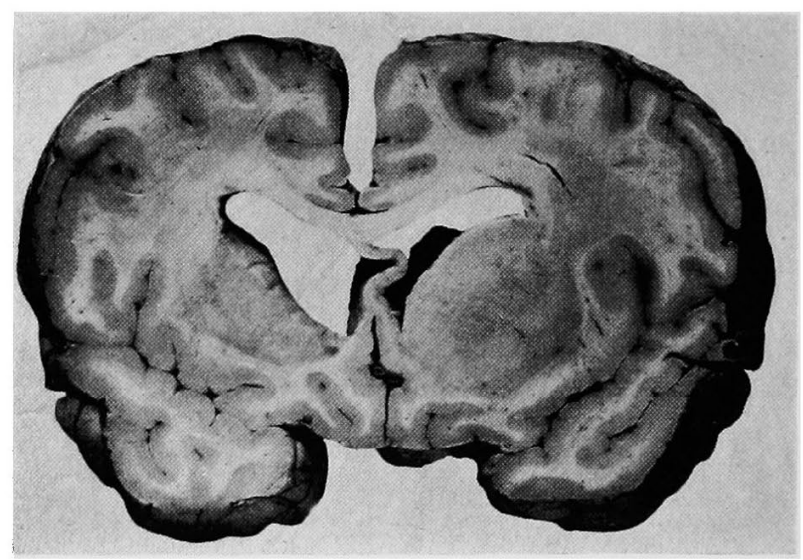

Fig. 10. Photograph of the tumor of the basal ganglia and the diencephalon. (Clinical case No. 12, Oki, 12 years old, female, died after operation)

The left striate body was invaded by the tumor and was enlarged.

Hepatic function was disturbed before operation: serum protein $8.2 \mathrm{~g} / \mathrm{dl}$, Meulengracht's index 8 , urobilinogen in urine $(+)$, serum cobalt reaction $7(8)$, serum cadmium reaction 5, Lugol reaction (H), Takata's reaction (+), CCF-test $(+)$, BSP clearance $4 \%$, serum cholesterol $186 \mathrm{mg} / \mathrm{dl}$, blood sugar $82 \mathrm{mg} / \mathrm{dl}$. Judgement of summarized functional disorders (H).

(2) Liver function in the group of the cortex and subcortical white matter (Tab. 2):

Four of 24 cases (11.6 percent) in this group showed disorders of the hepatic function. Two cases showing intensive disturbance of the hepatic function were the meningiomas in the right parietal and the left frontal regions, respectively. The other 2 cases were the contusions in the frontal lobe.

(3) Liver function in the group of the hypophyseal region (Tab. 3):

Disorder of the hepatic function was seen in 1 of 3 cases of this group, and the other 2 cases showed no particular impairment of the hepatic function.

(4) Liver function in the group of the infratentorial region (Tab. 4):

This group contained the cases of the brain tumors in the medulla oblongata, the pons, and the cerebellum. Three of 7 cases in this group were the tumors of the cerebellar vermis. Two of them showed disorders of the hepatic function. The tumor cases of the other regions showed no marked disturbance of the liver function.

2. Result of the studies on the autopsy cases (Tab. 5).

The cases where the cerebral lesions extended too widely to determine the precise site, were skipped out of examination. According to the site of the cerebral 
lesions, the cases were classified into 5 groups: the group of the basal ganglia, the group of the cortex and the subcortical white matter, the group of the hypophyseal region, the group of the thalamus and hypothalamus, and the group of the infratentorial region.

(1) Findings of the liver in the group of the basal ganglia:

This group contained 8 brain tumor and 26 intracerebral hemorrhage cases and their age ranged from 1 year and 7 months to 90 years. The hepatic lesions were seen in 16 cases ( 47.0 percent), particularly marked changes were seen in 5 cases ( 14.7 percent).

(2) Findings of the liver in the group of the cortex and the subcortical white matter:

This group was composed of 19 tumor and 11 trauma cases which ranged from 6 months to 70 years old. The liver damages were seen in 6 cases $(20.0$ percent), particularly marked changes were seen in 2 cases $(6.7$ percent).

(3) Findings of the liver in the group of the thalamus and the hypothalamus:

This group contained 9 tumor and 9 trauma cases and their age ranged from 7 to 66 years. The hepatic damages were seen in 4 cases ( 22.2 percent), particularly marked changes were seen in 2 cases ( 11.1 percent). These 2 cases were tumors which invaded partially the basal ganglia.

(4) Findings of the liver in the group of the hypophyseal region:

In this group, the age ranged from 5 to 60 years. The hepatic lesions were seen in 3 of 10 cases ( 30.0 percent), and all 3 cases showed moderate changes.

(5) Findings of the liver in the group of the infratentorial region:

This group contained 26 tumor and 7 trauma or hemorrhage cases. They ranged from 1 year to 80 years old. The tumor cases were mostly seen in the youngers and the hemorrhagic diseases in the middle aged or the aged. The marked hepatic lesions were seen in 2 cases ( 6.1 percent). They were cases of tumors in the cerebellar vermis. In another case of the cerebellar vermis tumor hepatic lesion was also seen though in moderate degree.

3. Result of histological and histochemical examinations of the liver of the rabbit which has the experimentally implanted brain tumor (Fig. 11).

The experimental animals were divided into 4 group according to the implanted site of the tumor ${ }^{31}$ ): the group of the caudate and the lenticular nuclei, the group of the cortex and subcortical white matter, the group of the thalamus and the hypothalamus and the group of the cerebellar region.

(1) Findings of the liver in the group of the caudate and the lenticular nuclei (Tab. 6):

Fourteen of 17 cases ( 88.4 percent) showed the hepatic damages of more than slight degree and 9 cases (53.0 percent) showed particular marked changes of the liver. Histological examination showed achromatization, melting, and necrosis 
Table 2. Liver functions in 24 cases where the brain tumor or brain

\begin{tabular}{|c|c|c|c|c|c|c|c|c|}
\hline Case No. & Patient & Sex & Age & Diagnosis & $\underset{\text { protein }}{\text { Serum }}$ & $\begin{array}{l}\text { Meulen- } \\
\text { gracht's } \\
\text { index }\end{array}$ & $\begin{array}{l}\text { Urobili- } \\
\text { nogen } \\
\text { in urine }\end{array}$ & $\begin{array}{c}\text { Serum } \\
\text { cobalt } \\
\text { reaction }\end{array}$ \\
\hline 13 & $\mathrm{HA}$ & 우 & 30 & Tumor & $6.9 \mathrm{~g} / \mathrm{dl}$ & 3 & $(-)$ & $3(5)$ \\
\hline 14 & OU & $\hat{s}$ & 27 & Tumor & 7.2 & 6 & $(+)$ & 3 \\
\hline 15 & HIS & 우 & 55 & Tumor & 7.0 & 4 & $(+)$ & -- \\
\hline 16 & $\mathrm{KU}$ & $\hat{b}$ & 38 & Tumor & 7.4 & 10 & $(+)$ & $3(5)$ \\
\hline 17 & FU & 令 & 44 & Contusion & 7.6 & 6 & $(+)$ & $4(6)$ \\
\hline 18 & OK & 占 & 37 & Contusion & 6.8 & 5 & $(t)$ & $0(4)$ \\
\hline 19 & $\mathrm{KY}$ & 占 & 15 & Hematoma & 5.8 & 5 & $(t)$ & $0(1)$ \\
\hline 20 & NI & $\hat{b}$ & 69 & Hematoma & 8.4 & 6 & $(t)$ & $3(4)$ \\
\hline 21 & F & $\hat{\sigma}$ & 44 & Hematoma & 7.0 & 4 & $(+)$ & $5(6)$ \\
\hline 22 & NA & 古 & 29 & Contusion & 6.8 & 6 & $(t)$ & $1(3)$ \\
\hline 23 & I & $\hat{\delta}$ & 28 & Tumor & 7.8 & 5.5 & $(+)$ & $2(3)$ \\
\hline 24 & UE & 오 & 54 & Tumor & 7.3 & 4 & $(t)$ & $1(5)$ \\
\hline 25 & NA & $\hat{\partial}$ & 47 & Tumor & 7.2 & 6 & $(+)$ & $4(5)$ \\
\hline 26 & NAK & 오 & 34 & Tumor & 7.2 & 4 & $(+)$ & $4(6)$ \\
\hline 27 & HIR & 令 & 4 & Tumor & 7.2 & 4 & $(+)$ & $0(3)$ \\
\hline 28 & MO & 우 & 42 & Tumor & 6.8 & 8 & $(+)$ & $4(7)$ \\
\hline 29 & IW & 疋 & 24 & Contusion & 6.4 & 4 & $(+)$ & $3(5)$ \\
\hline 30 & TAU & 우 & 10 & Contusion & 6.6 & 4 & $(+)$ & $3(5)$ \\
\hline 31 & SAS & $\delta$ & 27 & Contusion & 7.0 & 5 & $(+)$ & $0(4)$ \\
\hline 32 & NAG & 占 & 49 & Hematoma & 7.6 & 8 & $(+)$ & $0(3)$ \\
\hline 33 & NAK & $\delta$ & 9 & Hematoma & 7.0 & 5 & $(t)$ & $4(6)$ \\
\hline 34 & ASA & 우 & 16 & Tumor & 8.0 & 6 & $(+)$ & $0(4)$ \\
\hline 35 & WA & $\$$ & 42 & Tumor & 6.4 & 4 & $(t)$ & $0(3)$ \\
\hline 36 & SUG & 1 & 39 & Tumor & 7.4 & 3.5 & $(+)$ & $3(5)$ \\
\hline
\end{tabular}

Table 3. Liver functions in

\begin{tabular}{c|c|cc|l|c|c|c|c|}
\hline Case No. & Patient & Sex & Age & Diagnosis & $\begin{array}{c}\text { Serum } \\
\text { protein }\end{array}$ & $\begin{array}{c}\text { Meulen- } \\
\text { gracht's } \\
\text { index }\end{array}$ & $\begin{array}{c}\text { Urobili- } \\
\text { nogen } \\
\text { in urine }\end{array}$ & $\begin{array}{c}\text { Serum } \\
\text { cobalt } \\
\text { reaction }\end{array}$ \\
\hline 37 & TOK & \multirow{2}{*}{3} & 34 & Tumor & $7.6 \mathrm{~g} / \mathrm{dl}$ & 5 & $(+)$ & 3 \\
38 & IMA & \multirow{5}{*}{41} & Tumor & 7.4 & 3 & $(+)$ & $3(5)$ \\
39 & IID & \& & 24 & Tumor & 7.8 & 14 & $(+)$ & $0(4)$ \\
\hline
\end{tabular}

of the nuclei of the liver cells. And histochemical examination showed marked fatty deposition in the parenchymatous cells and Kupffer's cells.

(2) Findings of the liver in the group of the cortex and the subcortical white matter (Tab. 7):

In this group, 2 of 18 cases ( 11.1 percent) showed the hepatic lesions of 
trauma was in the cortex and the subcortical white matter.

\begin{tabular}{|c|c|c|c|c|c|c|c|}
\hline 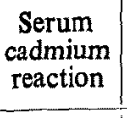 & $\begin{array}{c}\text { Lugol } \\
\text { reaction }\end{array}$ & $\begin{array}{l}\text { Takata's } \\
\text { reaction }\end{array}$ & $\begin{array}{l}\text { CCF } \\
\text { test }\end{array}$ & $\begin{array}{c}\text { BSP } \\
\text { clearance }\end{array}$ & $\underset{\text { cholesterol }}{\text { Serum }}$ & $\begin{array}{c}\text { Blood } \\
\text { sugar (in } \\
\text { hunger) }\end{array}$ & $\begin{array}{l}\text { Judge- } \\
\text { ment }\end{array}$ \\
\hline 7 & + & $-\quad-$ & $+H$ & $5.0 \%, 0 \%$ & $206 \mathrm{mg} / \mathrm{dl}$ & $45 \mathrm{mg} / \mathrm{dl}$ & $H$ \\
\hline 9 & - & $-\quad-$ & $-\quad-$ & $4.0,0$ & 158 & 76 & - \\
\hline - & - & $-\rightarrow$ & $-\quad-$ & - & 166 & $\longrightarrow$ & - \\
\hline 7 & - & -- & $-\quad-$ & - & 129 & 89 & \pm \\
\hline 7 & - & $-\quad-$ & $-H$ & $5.0,2.0$ & - & 90 & \pm \\
\hline 8 & - & $-\quad-$ & $-\quad+$ & $6.0,3.0$ & 168 & 92 & - \\
\hline 9 & - & $-\quad-$ & $-\quad-$ & $3.0,0$ & - & 82 & - \\
\hline 7 & - & $+H$ & -+ & $6.0,2.0$ & 196 & 129 & \pm \\
\hline - & - & $-\quad-$ & $-\quad-$ & $4.0,0$ & - & 64 & - \\
\hline 12 & - & $-\quad-$ & $-\quad-$ & $12 \quad, 7.5$ & 182 & 74 & + \\
\hline 9 & - & $-\quad-$ & $-\quad-$ & $4.0,0$ & 168 & 72 & - \\
\hline 0 & - & $-\quad-$ & $-\quad-$ & $\longrightarrow$ & 240 & 100 & - \\
\hline 8 & - & $-\quad-$ & - & $3.0,0$ & 182 & 76 & - \\
\hline 9 & - & $-\quad-$ & -+ & $5.0,2.0$ & 198 & 74 & - \\
\hline- & - & $-\quad-$ & -- & - & 168 & 78 & - \\
\hline 一 & - & $+H$ & ++ & $6.0,3.0$ & 198 & 82 & $H$ \\
\hline 8 & - & - & -+ & - & 182 & 84 & - \\
\hline 8 & - & - & -+ & - & $\longrightarrow$ & 78 & - \\
\hline 8 & - & $+H$ & $+H$ & $7.0,3.0$ & 182 & 88 & + \\
\hline 9 & - & $-\quad-$ & -- & $5.0,0$ & 186 & 100 & - \\
\hline 9 & - & $-\quad-$ & $-\quad-$ & - & 176 & 78 & - \\
\hline 8 & - & $-\quad-$ & -- & $5.0,2.0$ & 172 & 82 & - \\
\hline 12 & - & $-\quad-$ & $-\quad-$ & $4.0,0$ & 168 & 74 & - \\
\hline 9 & - & $-\quad-$ & $-\quad-$ & $3.5,2.0$ & 182 & 83 & - \\
\hline
\end{tabular}

3 cases with hypophyseal tumors.

\begin{tabular}{|c|c|c|c|c|c|c|c|}
\hline $\begin{array}{l}\text { Serum } \\
\text { cadmium } \\
\text { reaction }\end{array}$ & $\begin{array}{l}\text { Lugol } \\
\text { reaction }\end{array}$ & $\begin{array}{l}\text { Takata's } \\
\text { reaction }\end{array}$ & $\begin{array}{c}\mathrm{CCF} \\
\text { test }\end{array}$ & $\begin{array}{c}\text { BSP } \\
\text { clearance }\end{array}$ & $\begin{array}{c}\text { Serum } \\
\text { cholesterol }\end{array}$ & $\begin{array}{l}\text { Blood } \\
\text { sugar }\end{array}$ & $\begin{array}{l}\text { Judge- } \\
\text { ment }\end{array}$ \\
\hline 10 & - & $-\quad-$ & - \pm & $5.0 \%, 2.0 \%$ & $156 \mathrm{mg} / \mathrm{dl}$ & $70 \mathrm{mg} / \mathrm{dl}$ & - \\
\hline 7 & - & $-\quad-$ & $-H$ & $4.0,0$ & 172 & 82 & \pm \\
\hline 9 & - & $-\quad-$ & -+ & $5.0,0$ & 314 & 108 & + \\
\hline
\end{tabular}

slight degree. However, marked congestion of the liver was generally seen in this group, particularly intensive congestion was seen in 4 of 9 cases (44.4 percent) in the group of the subcortical white matter. There were also many cases in this group showing moderate congestion in the other organs than the liver. 
Table 4. Liver function of 7 cases

\begin{tabular}{|c|c|c|c|c|c|c|c|c|}
\hline Case No. & Patient & Sex & Age & Site of tumor & $\begin{array}{l}\text { Serum } \\
\text { protein }\end{array}$ & $\begin{array}{l}\text { Meulen- } \\
\text { gracht's } \\
\text { index }\end{array}$ & $\begin{array}{l}\text { Urobili- } \\
\text { nogen } \\
\text { in urine }\end{array}$ & $\begin{array}{c}\text { Serum } \\
\text { cobalt } \\
\text { reaction }\end{array}$ \\
\hline 40 & $\mathrm{KA}$ & $\delta$ & 21 & $\begin{array}{l}\text { Cerebell. } \\
\text { vermis. }\end{array}$ & $7.7 \mathrm{~g} / \mathrm{dl}$ & 6 & $(+)$ & $3(5)$ \\
\hline 41 & MUR & 오 & 39 & $\begin{array}{l}\text { Cerebell. } \\
\text { pontine angle }\end{array}$ & 6.4 & 4.5 & $(+)$ & $3(5)$ \\
\hline 42 & IKE & $\$$ & 17 & $\begin{array}{l}\text { Cerebell. } \\
\text { vermis. }\end{array}$ & 7.0 & 7 & $(+)$ & $1(3)$ \\
\hline 43 & $\mathrm{KAI}$ & 우 & 14 & $\begin{array}{l}\text { Cerebell. } \\
\text { vermis. }\end{array}$ & 6.2 & 5.2 & $(+)$ & $1(3)$ \\
\hline 44 & SUZ & 우 & 46 & $\begin{array}{l}\text { Cerebell. } \\
\text { pontine angle }\end{array}$ & 7.3 & 5 & $(+)$ & $3(5)$ \\
\hline 45 & $\mathrm{E}$ & 우 & 47 & $\begin{array}{l}\text { Cerebell. } \\
\text { pontine angle }\end{array}$ & 7.4 & 5 & $(+)$ & $5(6)$ \\
\hline 46 & MOT & 우 & 41 & $\begin{array}{l}\text { Semisph. } \\
\text { cerebell. }\end{array}$ & 6.8 & 4 & $(+)$ & $2(4)$ \\
\hline
\end{tabular}

Table 5. Hepatic damages in the autopsy cases of the brain tumor and the brain disease

\begin{tabular}{|c|c|c|c|c|c|c|}
\hline \multirow{2}{*}{ Site of disease } & \multicolumn{2}{|c|}{ Number of cases } & \multicolumn{4}{|c|}{ Hepatic damage } \\
\hline & Tumor & Contusion & Severe & Moderate & Slight & No change \\
\hline Basal ganglia & 8 & 26 & $\begin{array}{l}5 \\
(14.7 \%)\end{array}$ & $(32.3 \%)$ & $(35.3 \%)$ & $\begin{array}{c}6 \\
(17.6 \%)\end{array}$ \\
\hline $\begin{array}{l}\text { Thalamus, hypo- } \\
\text { thalamus } \\
18\end{array}$ & 9 & 9 & $(11.1 \%)$ & $(11.1 \%)$ & $\begin{array}{c}6 \\
(33.3 \%)\end{array}$ & $\begin{array}{c}8 \\
(44.5 \%)\end{array}$ \\
\hline $\begin{array}{l}\text { Cortex, subcortical } \\
\text { white matter } \\
\qquad 29\end{array}$ & 18 & 11 & $(6.9 \%)$ & $\begin{array}{c}3 \\
(10.2 \%)\end{array}$ & $\begin{array}{c}10 \\
(34.5 \%)\end{array}$ & $\begin{array}{c}14 \\
(48.4 \%)\end{array}$ \\
\hline $\begin{array}{l}\text { Hypophyseal } \\
\text { region } \\
\end{array}$ & 11 & 0 & $\left(\begin{array}{c}0 \\
(0 \%\end{array}\right)$ & $(36.3 \%)$ & $\begin{array}{c}5 \\
(45.4 \%)\end{array}$ & $(18.3 \%)$ \\
\hline $\begin{array}{l}\text { Pons, cerebellum, } \\
\text { medulla oblongata } \\
\quad 33\end{array}$ & 26 & 7 & $(6.1 \%)$ & $\begin{array}{c}5 \\
(15.1 \%)\end{array}$ & $\begin{array}{c}15 \\
(41.5 \%)\end{array}$ & $\begin{array}{c}11 \\
(37.3 \%)\end{array}$ \\
\hline $\begin{array}{c}\text { Total } \\
125\end{array}$ & 72 & 53 & 11 & 25 & 48 & 14 \\
\hline
\end{tabular}


of the infratentorial tumors.

\begin{tabular}{|c|c|c|c|c|c|c|c|}
\hline $\begin{array}{l}\text { Serum } \\
\text { cadmium } \\
\text { reaction }\end{array}$ & $\begin{array}{l}\text { Lugol } \\
\text { reaction }\end{array}$ & $\begin{array}{l}\text { Takata's } \\
\text { reaction }\end{array}$ & $\begin{array}{l}\text { CCF } \\
\text { test }\end{array}$ & $\begin{array}{c}\text { BSP } \\
\text { clearance }\end{array}$ & $\begin{array}{c}\text { Serum } \\
\text { cholesterol }\end{array}$ & $\begin{array}{l}\text { Blood } \\
\text { sugar }\end{array}$ & $\begin{array}{l}\text { Judge- } \\
\text { ment }\end{array}$ \\
\hline 9 & - & $-\quad-$ & $+H$ & $5.0 \%, 0 \%$ & $196 \mathrm{mg} / \mathrm{dl}$ & $78 \mathrm{mg} / \mathrm{dl}$ & + \\
\hline 7 & - & $-\quad-$ & $-\quad+$ & $3.0,0$ & 184 & 82 & - \\
\hline 10 & - & $-\quad-$ & -+ & $6.0,2.0$ & 168 & 76 & - \\
\hline 10 & - & ++ & $H \quad H$ & $6.0,2.0$ & - & 72 & + \\
\hline 7 & - & $-\quad-$ & -+ & - & 164 & - & - \\
\hline - & - & $-\quad-$ & -+ & $4.0,0$ & - & 76 & - \\
\hline 7 & - & $-\quad-$ & - & $3.0,0$ & 166 & 78 & - \\
\hline
\end{tabular}

Fig. 11. The site of the experimental brain tumors where hepatic damages were shown (rabbits).

- Severe hepatic damage. $H, H$

- Slight hepatic damage. + ,

O No change. \pm , -

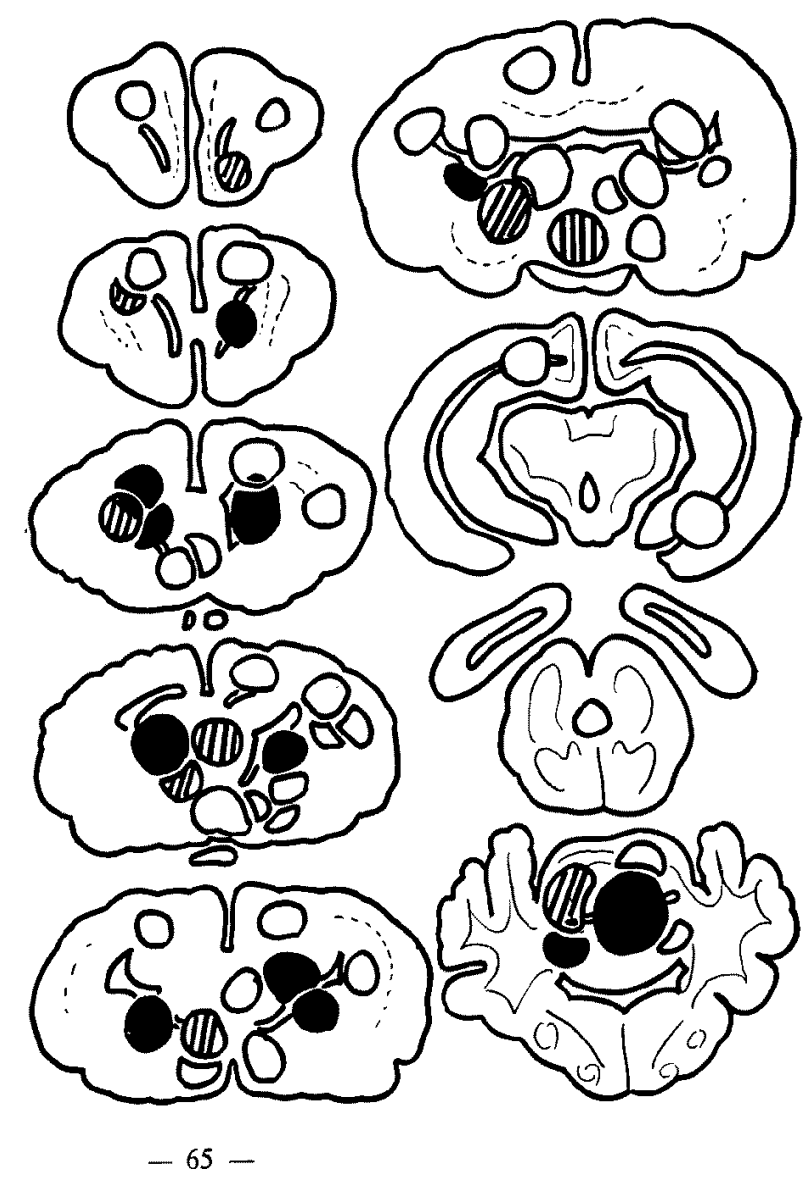


Table 6. Hepatic damages of the rabbits where the experimental

\begin{tabular}{|c|c|c|c|c|c|c|c|}
\hline \multirow[b]{2}{*}{$\begin{array}{l}\text { Case } \\
\text { No. }\end{array}$} & \multirow[b]{2}{*}{ Site of tumor } & \multirow[b]{2}{*}{$\begin{array}{c}\text { Survival } \\
\text { time } \\
\text { (days) }\end{array}$} & \multicolumn{5}{|c|}{ Parenchyma } \\
\hline & & & Swelling & $\begin{array}{c}\text { Appear- } \\
\text { ance of } \\
\text { abnormal } \\
\text { granules }\end{array}$ & $\begin{array}{l}\text { Atrophy } \\
\text { of liver } \\
\text { cell }\end{array}$ & $\begin{array}{l}\text { Achro- } \\
\text { matiza- } \\
\text { tion of } \\
\text { nuclei }\end{array}$ & $\begin{array}{l}\text { Melting } \\
\text { or } \\
\text { necrosis }\end{array}$ \\
\hline 10 & Caudate nucleus & 18 & H & + & - & + & - \\
\hline 11 & Caudate nucleus & 14 & $H$ & $H$ & - & + & H \\
\hline 12 & Caudate nucleus & 14 & - & - & H & - & - \\
\hline 13 & Caudate nucleus & 16 & $H$ & + & - & - & - \\
\hline 16 & Caudate nucleus & 15 & + & $H$ & + & + & + \\
\hline 25 & Caudate nucleus & 15 & + & $H$ & + & + & + \\
\hline 34 & Caudate nucleus & 15 & H & 世 & - & + & H \\
\hline 39 & Caud. \& lent. nuc. & 12 & H & W & - & + & + \\
\hline 41 & Caud. \& lent. nuc. & 14 & + & + & - & - & - \\
\hline 42 & Caud. \& lent. nuc. & 14 & $H$ & $H$ & - & - & - \\
\hline 45 & Caud. \& lent. nuc. & 18 & $H$ & $H$ & - & - & - \\
\hline 51 & Caud. \& lent. nuc. & 23 & H & H & - & + & + \\
\hline 55 & Caud. \& lent. nuc. & 20 & m & H & - & - & - \\
\hline 59 & Caud. \& lent. nuc. & 20 & + & + & - & - & - \\
\hline 63 & Caud. \& lent. nuc. & 18 & + & + & - & - & - \\
\hline 65 & Caud. \& lent. nuc. & 18 & $H$ & + & - & - & - \\
\hline 71 & Caud. \& lent. nuc. & 18 & $H$ & $H$ & - & - & + \\
\hline
\end{tabular}

(3) Findings of the liver in the group of the thalamus and the hypothalamus (Tab. 8):

In the group of the hypothalamus, the hepatic damages were observed in 3 of 11 cases ( 27.3 percent). In the group of the thalamus the hepatic lesion occurred much more slightly, that is, only slight swelling of the liver cell and an appearance of abnormal granules were observed in 2 of 6 cases.

(4) Findings of the liver in the group of the cerebellar region (Tab. 9):

In the cases of this group, congestion of the liver was slight in general. However, the hepatic lesions appeared so intensively that the lesions were seen in 8 of 10 cases ( 80 percent) and the marked ones were seen in 4 cases ( 40 percent).

4. Result of examination of the hepatic blood flow when an electrocoagulation was inflicted on the brain of the dog (Fig. 12).

According to the electrocoagulated site of the brain, the experimental animals were divided into 4 groups: the group of the caput nuclei caudati, the group of the cortex and subcortical white matter, the group of the thalamus and the hypothalamus and the group of the amygdaloid nucleus. The amygdaloid nucleus has a small area, forming a part of the basal ganglia, and occupying a ceiling of the parietal 
tumors were implanted in the caudate and the lenticular nuclei.

\begin{tabular}{|c|c|c|c|c|c|c|c|c|c|}
\hline \multicolumn{3}{|c|}{ Stroma } & \multirow{2}{*}{$\begin{array}{c}\text { Gly- } \\
\text { cogen, } \\
\text { PAS } \\
\text { reaction }\end{array}$} & \multirow[b]{2}{*}{$\begin{array}{l}\text { Fat, } \\
\text { Sudan } \\
\text { III }\end{array}$} & \multicolumn{2}{|c|}{ Phosphatase } & \multicolumn{2}{|c|}{ Nucleic acid } & \multirow[b]{2}{*}{$\begin{array}{c}\text { Judge- } \\
\text { ment }\end{array}$} \\
\hline $\begin{array}{l}\text { Dilatation } \\
\text { of vein }\end{array}$ & $\begin{array}{c}\text { Dilatation } \\
\text { of bile } \\
\text { duct }\end{array}$ & $\begin{array}{c}\text { Cell } \\
\text { infil- } \\
\text { tration }\end{array}$ & & & alkaline & acid & RNA & DNA & \\
\hline+ & - & + & $\downarrow$ & $\uparrow$ & $\downarrow$ & $\downarrow$ & $\fallingdotseq$ & $\doteqdot$ & $H$ \\
\hline$H$ & - & - & $\downarrow$ & $\uparrow$ & $\downarrow$ & $\fallingdotseq$ & $\fallingdotseq$ & $\fallingdotseq$ & H \\
\hline H & - & - & $\downarrow$ & $\downarrow$ & $\fallingdotseq$ & $\downarrow$ & $\fallingdotseq$ & $\doteqdot$ & - \\
\hline+ & + & - & $\downarrow$ & $\uparrow$ & $\downarrow$ & $\downarrow$ & $\uparrow$ & $\uparrow$ & + \\
\hline H & - & - & $\downarrow$ & $\uparrow$ & $\uparrow$ & $\downarrow$ & $\downarrow$ & $\downarrow$ & H \\
\hline$H$ & - & - & $\downarrow$ & $\uparrow$ & $\uparrow$ & $\downarrow$ & $\downarrow$ & $\downarrow$ & \# \\
\hline$H$ & - & - & $\downarrow$ & $\uparrow$ & $\downarrow$ & $\doteqdot$ & $\doteqdot$ & $\fallingdotseq$ & $H$ \\
\hline+ & - & - & $\downarrow$ & $\uparrow$ & $\downarrow$ & $\downarrow$ & $\fallingdotseq$ & $\fallingdotseq$ & \# \\
\hline+ & - & - & $\downarrow$ & $\uparrow$ & $\doteqdot$ & $\doteqdot$ & $\fallingdotseq$ & $\fallingdotseq$ & + \\
\hline+ & - & - & $\downarrow$ & $\downarrow$ & $\downarrow$ & $\downarrow$ & $\fallingdotseq$ & $\fallingdotseq$ & + \\
\hline+ & - & - & $\downarrow$ & $\uparrow$ & $\downarrow$ & $\downarrow$ & $\fallingdotseq$ & $\fallingdotseq$ & $H$ \\
\hline+ & - & - & $\downarrow$ & $\uparrow$ & $\downarrow$ & $\downarrow$ & $\fallingdotseq$ & $\fallingdotseq$ & W \\
\hline+ & - & - & $\downarrow$ & $\downarrow$ & $\downarrow$ & $\downarrow$ & $\doteqdot$ & $\fallingdotseq$ & + \\
\hline- & - & - & $\downarrow$ & $\uparrow$ & $\downarrow$ & $\downarrow$ & $\doteqdot$ & $\fallingdotseq$ & \pm \\
\hline+ & - & - & $\downarrow$ & $\uparrow$ & $\downarrow$ & $\downarrow$ & $\doteqdot$ & $\fallingdotseq$ & + \\
\hline+ & - & - & $\fallingdotseq$ & $\fallingdotseq$ & $\downarrow$ & $\fallingdotseq$ & $\fallingdotseq$ & $\fallingdotseq$ & \pm \\
\hline+ & - & - & $\downarrow$ & $\uparrow$ & $\downarrow$ & $\downarrow$ & $\fallingdotseq$ & $\fallingdotseq$ & H \\
\hline
\end{tabular}

angle of the lateral ventricle. The hepatic blood flow decreased in general after destruction was inflicted on either site in the brain. However, degree of decreasing varied with the site of destruction.

(1) Hepatic blood flow in the group where the caput nuclei caudati was destroyed (using 14 dogs); (Fig. 13):

The hepatic blood flow in this group one hour after destruction showed 89.5 percent (99.0-92.4 percent) of the preoperative value, that 3 hours after destruction 75.5 percent (83.5-66.5 percent) and that 5 hours after destruction 61.1 percent (67.3-52.8 percent), respectively.

(2) Hepatic blood flow in the group where the cortex and the subcortical white matter were destroyed (using 12 dogs):

The hepatic blood flow in this group one hour after destruction showed 92.8 percent (106-86.7 percent) of the preoperative value, that 3 hours after destruction 90.2 percent (102-81.5 percent), and that 5 hours after destruction 89.4 percent (98.8-78.2 percent), respectively. In 2 cases, the hepatic blood flow 3 hours after destruction showed the values more than the preoperative ones.

(3) Hepatic blood flow in the group where the thalamus and the hypothalamus were destroyed (using 11 dogs): 
Table 7. Hepatic damages of the rabbits where the experimental

\begin{tabular}{|c|c|c|c|c|c|c|c|}
\hline \multirow[b]{2}{*}{$\begin{array}{l}\text { Case } \\
\text { No. }\end{array}$} & \multirow[b]{2}{*}{ Site of tumor } & \multirow[b]{2}{*}{$\begin{array}{c}\text { Sur- } \\
\text { vival } \\
\text { time } \\
\text { (days) }\end{array}$} & \multicolumn{5}{|c|}{ Parenchyma } \\
\hline & & & $\begin{array}{c}\text { Swell- } \\
\text { ing }\end{array}$ & $\begin{array}{l}\text { Appear- } \\
\text { ance of } \\
\text { abnormal } \\
\text { granules }\end{array}$ & $\begin{array}{l}\text { Atrophy } \\
\text { of liver } \\
\text { cell }\end{array}$ & $\begin{array}{l}\text { Achro- } \\
\text { matiza- } \\
\text { tion of } \\
\text { nuclei }\end{array}$ & $\begin{array}{l}\text { Melting } \\
\text { of } \\
\text { necrosis }\end{array}$ \\
\hline 2 & Cortex & 14 & - & + & + & - & - \\
\hline 3 & Cortex & 14 & - & - & - & - & - \\
\hline 6 & Cortex & 14 & - & + & + & - & - \\
\hline 9 & Cortex & 18 & - & - & - & - & - \\
\hline 14 & Cortex & 18 & + & + & + & - & - \\
\hline 15 & Cortex & 18 & \pm & + & - & - & - \\
\hline 24 & Cortex & 19 & - & - & - & - & - \\
\hline 37 & Cortex & 23 & - & - & - & - & - \\
\hline 57 & Cortex & 15 & + & + & + & - & - \\
\hline 8 & Subcortical white matter & 15 & - & - & $H$ & - & - \\
\hline 18 & Subcortical white matter & 10 & + & - & + & - & - \\
\hline 23 & Subcortical white matter & 14 & + & + & - & - & - \\
\hline 26 & Subcortical white matter & 14 & - & + & - & - & - \\
\hline 28 & Subcortical white matter & 14 & - & - & + & - & - \\
\hline 29 & Subcortical white matter & 16 & - & + & + & - & - \\
\hline 36 & Subcortical white matter & 16 & + & + & - & - & - \\
\hline 48 & Subcortical white matter & 17 & - & - & - & - & - \\
\hline 49 & Subcortical white matter & 17 & \pm & + & - & - & - \\
\hline
\end{tabular}

The hepatic blood flow in this group one hour after destruction showed 90.4 percent (95.7-81.8 percent) of the preoperative value, that 3 hours after destruction 85.1 percent (90.7-76.7 percent) and that 5 hours after destruction 82.8 percent (88.7-77.2 percent), respectively.

(4) Hepatic blood flow in the group where the amygdaloid nucleus was destroyed (using 4 dogs):

The hepatic blood flow in this group one hour after destruction showed 89.1 percent (91.2-86.7 percent) of the preoperative value, that 3 hours after destruction 83.0 percent (86.1-81.0 percent) and that 5 hours after destruction 79.8 percent (83.8-77.4 percent), respectively.

\section{Discussion}

In the hepatolenticular degeneration reported by Wilson in 1912, organic change of the brain around the lenticular nuclei was recognized together with the characteristic liver cirrhosis of the gross nodular type. At first, this change was regarded merely as a systemic degenerative process. However, after Bols ${ }^{5}$ ) in 1926, 
tumors were implanted in the cortex and the subcortical white matter.

\begin{tabular}{|c|c|c|c|c|c|c|c|c|c|}
\hline \multicolumn{3}{|c|}{ Stroma } & \multirow{2}{*}{$\begin{array}{l}\text { Gly- } \\
\text { cogen, } \\
\text { PAS } \\
\text { reaction }\end{array}$} & \multirow[b]{2}{*}{$\begin{array}{l}\text { Fat, } \\
\text { Sudan } \\
\text { III }\end{array}$} & \multicolumn{2}{|c|}{ Phosphatase } & \multicolumn{2}{|c|}{ Nucleic acid } & \multirow[b]{2}{*}{$\begin{array}{l}\text { Judge- } \\
\text { ment }\end{array}$} \\
\hline $\begin{array}{l}\text { Dilatation } \\
\text { of vein }\end{array}$ & $\begin{array}{c}\text { Dilatation } \\
\text { of bile } \\
\text { duct }\end{array}$ & $\begin{array}{c}\text { Cell } \\
\text { infil- } \\
\text { tration }\end{array}$ & & & alkaline & acid & RNA & DNA & \\
\hline+ & - & - & $\fallingdotseq$ & $\fallingdotseq$ & $\fallingdotseq$ & $\fallingdotseq$ & $\fallingdotseq$ & $\fallingdotseq$ & \pm \\
\hline+ & - & - & $\doteqdot$ & $\fallingdotseq$ & $\because$ & $\fallingdotseq$ & & & - \\
\hline+ & - & - & $\uparrow$ & $\fallingdotseq$ & $\downarrow$ & $\downarrow$ & & & - \\
\hline+ & - & - & $\fallingdotseq$ & $\fallingdotseq$ & $\fallingdotseq$ & $\doteqdot$ & $\fallingdotseq$ & $\fallingdotseq$ & - \\
\hline+ & - & - & $\downarrow$ & $\uparrow$ & $\downarrow$ & $\downarrow$ & & & + \\
\hline- & - & - & $\doteqdot$ & $\fallingdotseq$ & $\downarrow$ & $\downarrow$ & $\downarrow$ & $\fallingdotseq$ & \pm \\
\hline- & - & - & $\doteqdot$ & $\fallingdotseq$ & $\fallingdotseq$ & $\doteqdot$ & $\fallingdotseq$ & $\fallingdotseq$ & - \\
\hline+ & - & - & $\fallingdotseq$ & $\fallingdotseq$ & $\doteqdot$ & $\doteqdot$ & $\fallingdotseq$ & $\fallingdotseq$ & - \\
\hline H & - & + & $\uparrow$ & $\fallingdotseq$ & $\downarrow$ & $\downarrow$ & $\fallingdotseq$ & $\doteqdot$ & \pm \\
\hline H & - & - & $\downarrow$ & $\downarrow$ & $\uparrow$ & $\downarrow$ & & & - \\
\hline H & - & - & $\downarrow$ & $\downarrow$ & $\fallingdotseq$ & $\fallingdotseq$ & $\downarrow$ & $\doteqdot$ & \pm \\
\hline$H$ & - & + & $\uparrow$ & $\uparrow$ & $\fallingdotseq$ & $\fallingdotseq$ & $\fallingdotseq$ & $\fallingdotseq$ & - \\
\hline+ & - & - & $\downarrow$ & $\fallingdotseq$ & $\fallingdotseq$ & $\fallingdotseq$ & & & - \\
\hline+ & - & - & $\fallingdotseq$ & $\doteqdot$ & $\fallingdotseq$ & $\fallingdotseq$ & $\fallingdotseq$ & $\fallingdotseq$ & - \\
\hline$H$ & - & - & $\fallingdotseq$ & $\fallingdotseq$ & $\fallingdotseq$ & $\fallingdotseq$ & $\downarrow$ & $\fallingdotseq$ & + \\
\hline- & - & - & $\fallingdotseq$ & $\uparrow$ & $\fallingdotseq$ & $\fallingdotseq$ & $\doteqdot$ & $\fallingdotseq$ & - \\
\hline+ & - & - & $\fallingdotseq$ & $\doteqdot$ & $\doteqdot$ & $\fallingdotseq$ & & & - \\
\hline \pm & - & - & $\fallingdotseq$ & $\fallingdotseq$ & $\fallingdotseq$ & $\doteqdot$ & $\fallingdotseq$ & $\fallingdotseq$ & - \\
\hline
\end{tabular}

reported an autopsy case of the encephalitic parkinsonism where organic changes in the mesencephalon (midbrain) and the diencephalon (interbrain) were observed simultaneously with marked changes of the liver, a positive consideration became to be paid on close correlation between the cerebral lesions and the hepatic disorders. Katzuki ${ }^{24)}$ performed functional tests of the liver on 7 cases showing the extrapyramidal symptoms and related that slight disorder of BSP clearance was seen in 3 cases, positive manifestation of serum colloidal reaction in 1 case, slight decrease of cholin esterase activity in 3 cases and moderate or slight impairment of function of disintoxication in 6 cases. Faust ${ }^{13)}$, Georgi ${ }^{16)}$ and Muramatsu ${ }^{299}$ also reported disorder of the liver functions in many cases of the extrapyramidal diseases. Regarding examination of the autopsy cases, Bauer ${ }^{(6)}$ and Northfield ${ }^{31)}$, besides Bolsi described that many of the tumor cases in the diencephalon were accompanied by endocrine disorders. As mentioned above, there have been only a few reports about functional changes of the liver in the cases of the cerebral organic lesions.

The present authors have performed functional tests of the liver on 46 clinical cases of the brain tumor and the brain trauma, and performed histological ex- 
Table 8. Hepatic damages of the rabbits where the experimental

\begin{tabular}{|c|c|c|c|c|c|c|c|}
\hline \multirow[b]{2}{*}{$\begin{array}{l}\text { Case } \\
\text { No. }\end{array}$} & \multirow[b]{2}{*}{ Site of tumor } & \multirow[b]{2}{*}{$\begin{array}{c}\text { Survival } \\
\text { time } \\
\text { (days) }\end{array}$} & \multicolumn{5}{|c|}{ Parenchyma } \\
\hline & & & Swelling & $\begin{array}{c}\text { Appear- } \\
\text { rance of } \\
\text { abnormal } \\
\text { granules }\end{array}$ & $\begin{array}{l}\text { Atrophy } \\
\text { of liver } \\
\text { cell }\end{array}$ & $\begin{array}{l}\text { Achro- } \\
\text { matiza- } \\
\text { tion of } \\
\text { nuclei }\end{array}$ & $\begin{array}{l}\text { Melting } \\
\text { or } \\
\text { necrosis }\end{array}$ \\
\hline 17 & Thalamus & 20 & + & - & - & - & - \\
\hline 22 & Thalamus & 18 & \pm & - & - & - & - \\
\hline 43 & Thalamus & 15 & + & \pm & - & - & - \\
\hline 52 & Thalamus & 15 & - & \pm & - & - & - \\
\hline 67 & Thalamus & 15 & - & \pm & + & - & - \\
\hline 70 & Thalamus & 15 & - & + & - & - & - \\
\hline 19 & Hypothalamus & 16 & - & \pm & - & - & - \\
\hline 20 & Hypothalamus & 15 & - & \pm & - & - & - \\
\hline 21 & Hypothalamus & 14 & + & + & - & - & - \\
\hline 30 & Hypothalamus & 14 & + & \pm & - & - & - \\
\hline 31 & Hypothalamus & 19 & + & + & - & - & - \\
\hline 32 & Hypothalamus & 18 & \pm & + & - & - & - \\
\hline 33 & Hypothalamus & 18 & \pm & + & - & - & - \\
\hline 35 & Hypothalamus & 18 & - & - & - & - & - \\
\hline 46 & Hypothalamus & 15 & + & + & - & - & - \\
\hline 47 & Hypothalamus & 17 & - & \pm & - & - & - \\
\hline 68 & Hypothalamus & 17 & \pm & \pm & - & - & - \\
\hline
\end{tabular}

Table 9. Hepatic damages of the rabbits where the

\begin{tabular}{c|c|c|c|c|c|c|c|}
\hline & & & \multicolumn{5}{|c|}{ Parenchyma } \\
\cline { 4 - 8 } $\begin{array}{c}\text { Case } \\
\text { No. }\end{array}$ & Site of tumor & $\begin{array}{c}\text { Survival } \\
\text { time } \\
\text { (days) }\end{array}$ & Swelling & $\begin{array}{c}\text { Appear- } \\
\text { ance of } \\
\text { abnormal } \\
\text { granules }\end{array}$ & $\begin{array}{c}\text { Atrophy } \\
\text { of liver } \\
\text { cell }\end{array}$ & $\begin{array}{c}\text { Achro- } \\
\text { matiza- } \\
\text { tion of } \\
\text { nuclei }\end{array}$ & $\begin{array}{c}\text { Melting } \\
\text { or } \\
\text { necrosis }\end{array}$ \\
\hline 44 & Cerebellum & 14 & + & + & - & + & + \\
53 & Cerebellum & 14 & + & + & - & - & - \\
54 & Cerebellum & 14 & + & + & - & - & - \\
56 & Cerebellum & 16 & + & + & - & + & - \\
58 & Cerebellum & 15 & + & + & - & - & - \\
60 & Cerebellum & 15 & + & + & + & + & + \\
61 & Cerebellum & 16 & + & + & - & - & - \\
64 & Cerebellum & 14 & + & + & - & + & - \\
66 & Cerebellum & 15 & \pm & + & - & - & - \\
69 & Cerebellum & 15 & \pm & \pm & - & - & - \\
\hline
\end{tabular}

aminations of the liver on 125 autopsy cases died of the cerebral tumors and the cerebral diseases. It was found that most of the hepatic damages were manifested 
tumors were implanted in the thalamus and the hypothalamus.

\begin{tabular}{|c|c|c|c|c|c|c|c|c|c|}
\hline \multicolumn{3}{|c|}{ Stroma } & \multirow{2}{*}{$\begin{array}{c}\text { Gly- } \\
\text { cogen, } \\
\text { PAS } \\
\text { reaction }\end{array}$} & \multirow[b]{2}{*}{$\begin{array}{l}\text { Fat, } \\
\text { Sudan } \\
\text { III }\end{array}$} & \multicolumn{2}{|c|}{ Phosphatase } & \multicolumn{2}{|c|}{ Nucleic acid } & \multirow[b]{2}{*}{$\begin{array}{c}\text { Judge- } \\
\text { ment }\end{array}$} \\
\hline $\begin{array}{c}\text { Dilatation } \\
\text { of vein }\end{array}$ & $\begin{array}{c}\text { Dilatation } \\
\text { of bile } \\
\text { duct }\end{array}$ & $\begin{array}{l}\text { Cell } \\
\text { infil- } \\
\text { tration }\end{array}$ & & & alkaline & acid & RNA & DNA & \\
\hline- & - & - & $\downarrow$ & $\uparrow$ & $\uparrow$ & $\uparrow$ & $\doteqdot$ & $\fallingdotseq$ & \pm \\
\hline+ & - & - & $\fallingdotseq$ & $\doteqdot$ & $\fallingdotseq$ & $\fallingdotseq$ & $\fallingdotseq$ & $\fallingdotseq$ & - \\
\hline+ & - & - & $\fallingdotseq$ & $\fallingdotseq$ & $\fallingdotseq$ & $\fallingdotseq$ & & & - \\
\hline+ & - & - & $\fallingdotseq$ & $\uparrow$ & $\uparrow$ & $\uparrow$ & $\fallingdotseq$ & $\fallingdotseq$ & \pm \\
\hline$H$ & - & - & $\fallingdotseq$ & $\fallingdotseq$ & $\fallingdotseq$ & $\uparrow$ & $\doteqdot$ & $\fallingdotseq$ & - \\
\hline+ & - & - & $\doteqdot$ & $\doteqdot$ & $\fallingdotseq$ & $\doteqdot$ & $\fallingdotseq$ & $\doteqdot$ & - \\
\hline+ & - & - & $\downarrow$ & $\uparrow$ & $\uparrow$ & $\uparrow$ & $\doteqdot$ & $\doteqdot$ & \pm \\
\hline+ & - & - & $\fallingdotseq$ & $\uparrow$ & $\doteq$ & $\fallingdotseq$ & $\doteqdot$ & $\fallingdotseq$ & \pm \\
\hline+ & - & - & $\fallingdotseq$ & $\fallingdotseq$ & $\doteqdot$ & $\doteqdot$ & & & - \\
\hline+ & - & - & $\fallingdotseq$ & $\doteqdot$ & $\doteqdot$ & $\doteqdot$ & $\fallingdotseq$ & $\fallingdotseq$ & - \\
\hline+ & - & - & $\fallingdotseq$ & $\fallingdotseq$ & $\doteqdot$ & $\fallingdotseq$ & $\fallingdotseq$ & $\doteqdot$ & - \\
\hline- & - & - & $\fallingdotseq$ & $\fallingdotseq$ & $\doteqdot$ & $\fallingdotseq$ & $\fallingdotseq$ & $\doteqdot$ & \pm \\
\hline+ & - & - & $\downarrow$ & $\doteqdot$ & $\fallingdotseq$ & $\fallingdotseq$ & $\downarrow$ & & + \\
\hline+ & - & - & $\fallingdotseq$ & $\uparrow$ & $\downarrow$ & $\downarrow$ & & & - \\
\hline- & - & - & $\uparrow$ & $\doteq$ & $\downarrow$ & $\downarrow$ & & & \pm \\
\hline+ & - & - & $\fallingdotseq$ & $\fallingdotseq$ & $\fallingdotseq$ & $\fallingdotseq$ & $\fallingdotseq$ & $\fallingdotseq$ & + \\
\hline+ & - & - & $\doteqdot$ & $\uparrow$ & $\fallingdotseq$ & $\doteqdot$ & & $\fallingdotseq$ & + \\
\hline
\end{tabular}

experimental tumor were implanted in the cerebellum.

\begin{tabular}{|c|c|c|c|c|c|c|c|c|c|}
\hline \multicolumn{3}{|c|}{ Stroma } & \multirow{2}{*}{$\begin{array}{c}\text { Gly- } \\
\text { cogen, } \\
\text { PAS } \\
\text { reaction }\end{array}$} & \multirow[b]{2}{*}{$\begin{array}{l}\text { Fat, } \\
\text { Sudan } \\
\text { III }\end{array}$} & \multicolumn{2}{|c|}{ Phosphatase } & \multicolumn{2}{|c|}{ Nucleic acid } & \multirow[b]{2}{*}{$\begin{array}{c}\text { Judge- } \\
\text { ment }\end{array}$} \\
\hline $\begin{array}{c}\text { Dilatation } \\
\text { of vein }\end{array}$ & $\begin{array}{c}\text { Dilatation } \\
\text { of bile } \\
\text { duct }\end{array}$ & $\begin{array}{l}\text { Cell } \\
\text { infil- } \\
\text { tration }\end{array}$ & & & alkaline & acid & RNA & DNA & \\
\hline+ & - & - & $\fallingdotseq$ & $\uparrow$ & $\downarrow$ & $\downarrow$ & $\downarrow$ & $\fallingdotseq$ & 册 \\
\hline \pm & - & - & $\doteqdot$ & $\uparrow$ & $\downarrow$ & $\downarrow$ & $\downarrow$ & $\fallingdotseq$ & + \\
\hline+ & - & - & $\uparrow$ & $\uparrow$ & $\doteqdot$ & $\doteqdot$ & $\fallingdotseq$ & $\doteqdot$ & + \\
\hline+ & - & - & $\fallingdotseq$ & $\fallingdotseq$ & $\fallingdotseq$ & $\fallingdotseq$ & $\fallingdotseq$ & $\fallingdotseq$ & $H$ \\
\hline+ & - & - & $\downarrow$ & $\uparrow$ & $\downarrow$ & $\downarrow$ & $\downarrow$ & $\fallingdotseq$ & + \\
\hline$H$ & - & - & $\downarrow$ & $\uparrow$ & $\uparrow$ & $\downarrow$ & $\downarrow$ & $\fallingdotseq$ & H \\
\hline+ & - & - & $\downarrow$ & $\fallingdotseq$ & $\downarrow$ & $\downarrow$ & $\downarrow$ & $\fallingdotseq$ & + \\
\hline+ & - & - & $\downarrow$ & $\uparrow$ & $\downarrow$ & $\downarrow$ & & & H \\
\hline+ & - & - & $\downarrow$ & $\uparrow$ & $\downarrow$ & $\downarrow$ & & & \pm \\
\hline+ & - & - & $\downarrow$ & $\fallingdotseq$ & $\doteqdot$ & $\doteqdot$ & $\fallingdotseq$ & $\fallingdotseq$ & - \\
\hline
\end{tabular}

in the cases where the cerebral lesions situated in the regions involving the basal ganglia and the diencephalon or in the cerebellar vermis. 


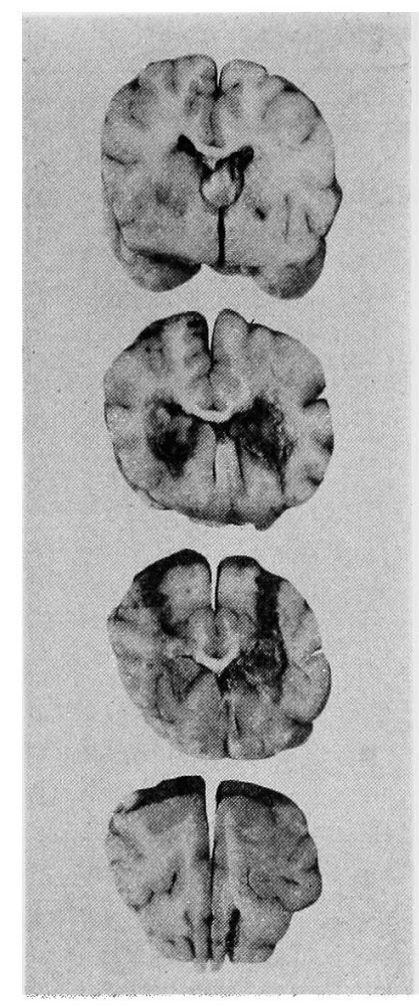

Fig. 12. Photograph of the brain where an electrocoagulation was inflicted upon (Dog No. 5).

Bilateral caput nuclei caudati were destroyed.

There has been no definite concept regarding relation between the site of the cerebral lesion and occurrence of the hepatic disorder. Boenheim described that the hepatic disorder was caused by the lesion of the thalamic centre. Nayrac ${ }^{32}$ said the gray substance of the infundibular region had a dominant relation to fat and carbohydrate metabolisms and the lesion of this region induced the hepatic change. Kurozu ${ }^{25)}$, using the rabbit, stimulated the sympathetic zone in the hypothalamus, and observed darkening of cell body of the liver, decrease of the ironcontained granules and vitamine $B_{1}$ in the liver cell and increase of phosphatase activity of the liver tissue. Asai ${ }^{48}$ ) observed atrophy and degeneration of the liver cell, enlargement of the hepatic sinus, and round cell infiltration in the liver tissue, at the time of cauterization of the hypothalamus. Yoshino ${ }^{46)}$ also destroyed the hypothalamus and noticed decrease of the body weight, lowering of the serum albumin level, and degeneration of the liver tissue. Usami et $\mathrm{al}^{42)}$ recognized occurrence of the hepatic damages, that is, vacuole formation, swelling of the liver cell and increase of activity of alkaline phosphatase in the surroundings of the liver cell after cauterization of the hypothalamus, the striate body and the mamillary body. Using 105 rabbits, Akiyama carried out electrical stimulation or electrocoagulation on the thalamus, the caudate nuclei, the globus pallidus and the puta- 
men. Observing changes of the liver for 24-48 hours, he found the hepatic fufnctions were disturbed when an intervention was inflicted upon the caudate nuclei, the globus pallidus and the putamen; no hepatic damage occurred when the thalamus was injured. And he noticed: an electrocoagulation of the brain induced the hepatic damage much more intensively than an electrical stimulation of the brain. The present authors implanted Brown-Pearce's cancer into the various regions of the brain of the rabbit and investigated histological and histochemical changes of the liver. Marked hepatic changes were caused when the tumor was implanted in the caudate and the lenticular nuclei. On the other hand, no any particular change of the liver was seen when the tumor was situated in the thalamus and the hypothalamus. Furthermore almost all the cases showed the marked damage of the liver, when the tumor was implanted in the cerebellum.

There are several factors which induced the hepatic damage. As an important one of them, the present authors noticed disorder of the hepatic blood flow. Thereupon, the following trial was done: the hepatic blood flow was measured and its change was observed before, 1 hour, 3 hours, and 5 hours after, electrocoagulation was made upon the various regions of the brain of dog. The present authors used $\mathrm{Au}^{198}$ colloid clearance method for measurement of the hepatic blood flow. After

1) The group of the caput nuclei caudati.

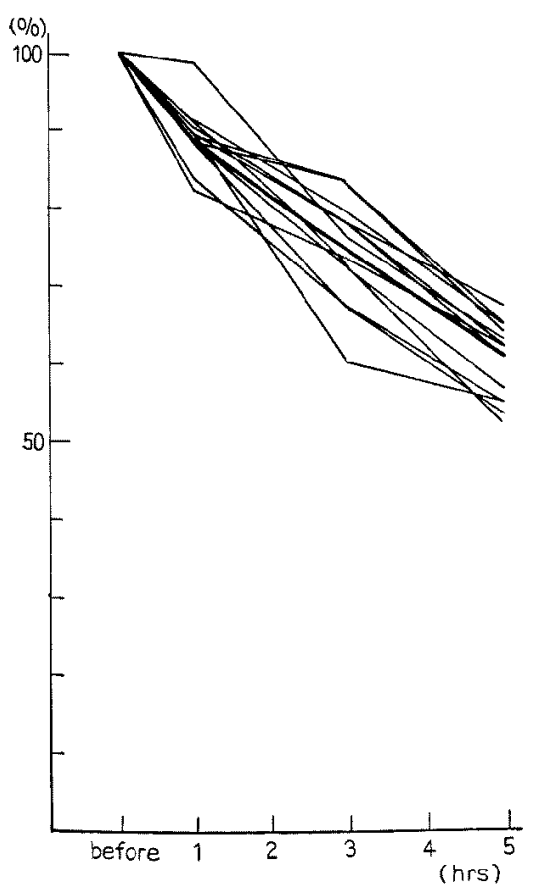

2) The group of the cortex and the subcortical white matter.
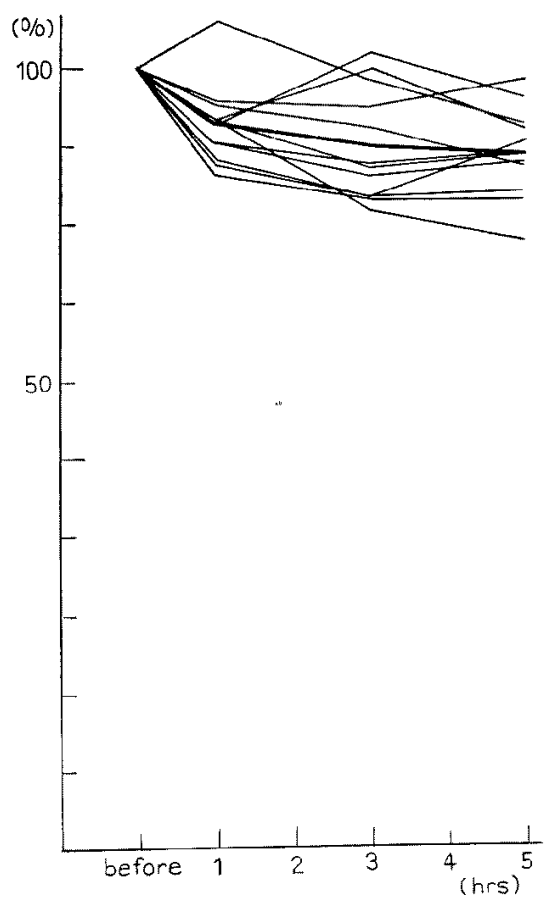
3) The group of the thalamus and the hypothalamus.

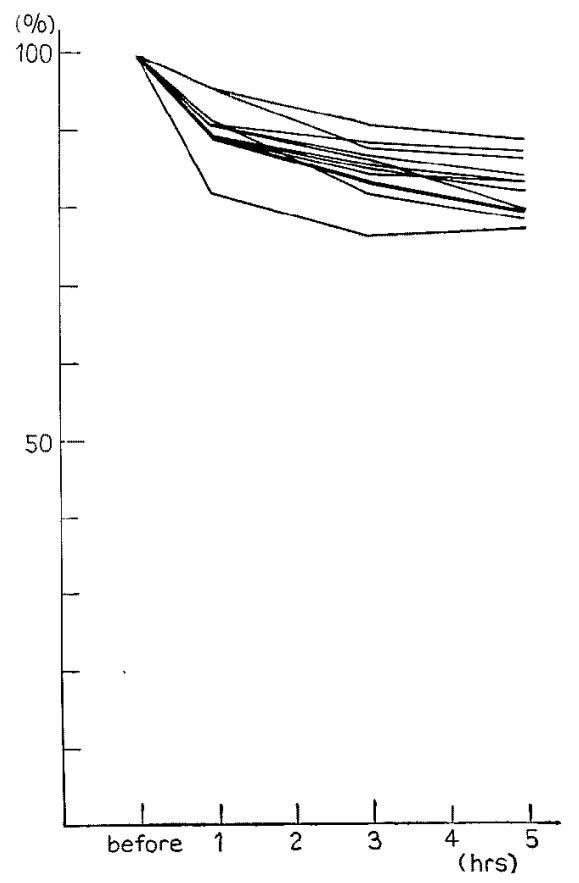

4) The group of the amygdaloid nucleus.

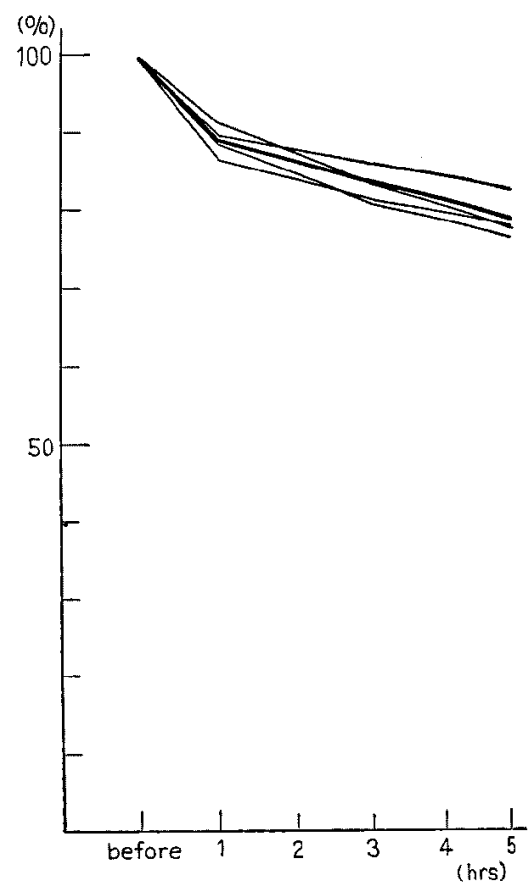

Fig. 13, Decrease of hepatic blood flow when the regions of the brain were experimentally destroyed.

intravenous injection of the colloid granules, they were uptaken mainly in the liver and the spleen. Therefore, uptake amount of colloid was a mathematical function of the hepatic blood flow. The hepatic blood flow could be calculated from the clearance curve in the blood taken after injection of $\mathrm{Au}^{198}$ colloid. This method for measuring the hepatic blood flow was possible for several repeated employments within a short period. According to the results of our examinations, more marked decrease of the hepatic blood flow was shown in the group of destruction of the caput nuclei caudati, compared with that in the group of destruction of other regions.

Summarizing the above mentioned results of examinations in the clinical and autopsy cases and of the experimental studies, the present authors verified that the hepatic damages occurred markedly when the cerebral lesions were situated in the caudate and the lenticular nuclei and their surroundings. Furthermore the present authors could assume that the hepatic damage in the case of the cerebral lesion was incurred by decrease of the hepatic blood flow.

In 1839 , Budge ${ }^{\text {t) }}$ advocated that the striate body was related to the visceral function, since intestinal movement became vigorous after insertion of the probe 
nto the striate body of dog. Bechterew $\left.{ }^{8}\right)$ described that the striate body was related o central regulation of the stomach, the intestine and the urine bladder. Durp and Dresel $^{12)}$ said that heat centre or the upper centre regulating carbohydrate and water metabolism was in the striate body. These phenomena described in the literature had a close relation to the present authors' results that destruction of the caudate and the lenticular nuclei invaded by tumor or the trauma, did result in the hepatic damage.

Suda ${ }^{41)}$ and $B$ an et $\mathrm{al}^{9,18)}$ verified that the cerebellum had a function regulating some autonomic activities. Ban explained the efferents from the cerebellum relaid to the hypothalamus, thus the cerebellum did an indirect regulation for the autonomic function. It has long been well known that the medulla oblongata adjacent to the cerebellum contained very important autonomic centre. $\mathrm{Cl}$. Bernard ${ }^{10)}$ long ago recognized elevation of the blood sugar level and increase of the hepatic blood flow after puncture of the reticular formation in the medulla. Since then, many of the similar reports were published ${ }^{11,33)}$.

According to the present authors' study, the hepatic damage occurred in a high rate when the lesions was situated in the cerebellar vermis or its surroundings. However, it is an unsolved problem whether the hepatic damage in the case of the cerebellar tumor was induced directly by relation to the cerebellar function or the hepatic damage was induced indirectly under mediation of the autonomic function in the medulla which was mechanically compressed by the cerebellar tumor.

It is also an unsolved problem whether the hepatic damage in the case of the cerebral lesion was caused by mechanical interruption or disturbance in the innervation of the liver, or the hepatic damage was caused by humoral disorder originated from the cerebral lesion.

\section{CONCLUSION}

1) Fourty-six clinical cases of the brain tumor and the brain trauma were classified into 4 groups according to the site of the diseases: the group of the basal ganglia and the diencephalon, the group of the cortex and the subcortical white matter, the group of the hypophyseal region and the group of the infratentorial region, and functional tests of the liver in these cases were done. In the group of the basal ganglia and the diencephalon, hepatic functional disorders appeared intensively, in the highest rate ( 83.6 percent) and subsequently in the cases of the cerebellar vermis tumors functional disturbance of the liver was of intensive. In the group of the cortex and the subcortical white matter and in the group of the hypophyseal region, the cases with functional disordcr of the liver were a few (16.6-33.3 percent) and degree of disorder was slight.

2) One hundred and twenty five autopsy cases of the brain tumor and the brain disease were divided into 5 groups according to the site of the diseases: the group of the basal ganglia, the group of the cortex and the subcortical white matter, 
the group of the hypophyseal region, the group of the thalamus and the hyp thalamus and the group of the infratentorial region, and histological examination of the liver in these cases were performed. In the cases belonging to the grou of the basal ganglia, the hepatic damages were observed in the highest inciden ( 47.0 percent) and intensively. On the other hand, in the group of the cortex an the subcortical white matter, the group of the hypophyseal region, the group c the thalamus and the hypothalamus, and the group of the infratentorial regior the hepatic damages were observed in lower rate (20.0-30.0 percent) and slightl in comparison with those in the group of the basal ganglia. However, histologict changes of the liver were observed intensely in the tumor cases of the cerebella vermis.

3) Using 71 adult rabbits, the experimental brain tumors were produce by transplantation of Brown-Pearce's cancer into the brains, and histological an histochemical examinations of the liver of these animals were performed. The ex perimental animals were classified into 4 groups according to the site of the im planted tumors: the group of the caudate and the lenticular nuclei, the group 0 the cortex and the subcortical white matter, the group of the thalamus and th hypothalamus and the group of the cerebellar region, and the results were com. pared among the groups. In the group of the caudate and the lenticular nuclei the incidence of appearance of the hepatic damages attained to 82.4 percent, beside: severe damages were shown in 53 percent of the cases. Subsequently in the grouf of the cerebellar region, the incidence of occurrence of the hepatic damages attainec to 80 percent and severe ones were seen in 40 percent. On the other hand, in the group of the cortex and the subcortical white matter and in the group of the thalamus and the hypothalamus, the incidence of appearance of the hepatic damages was small (11.1-17.7 percent) and degree of damage was slight.

4) Using 41 adult mongrel dogs, an electrocoagulations was made on the intended region of the brain. Changes of the hepatic blood flow subsequent to coagulation was examined by $\mathrm{Au}^{198}$ colloid clearance method. The experimental animals were classified into 4 groups according to the site of coagulation: the group of the caput nuclei caudati, the group of the cortex and the subcortical white matter, the group of the thalamus and the hypothalamus and the group of the amygdaloid nucleus. The results were compared among the groups. In the group of the caput nuclei caudati, decrease of the hepatic blood flow was the most significant: the hepatic blood flow one hour after coagulation showed 89.5 percent of the preoperative value, that 3 hours 75.5 percent and that 5 hours 61.1 percent, respectively. Decrease of the hepatic blood flow in the group of the cortex and the subcortical white matter and in the group of the thalamus and the hypothalamus was much slighter. 


\section{REFERENCES}

l) Albrink, W. S.: Cancer Res., 13, 64, 1953.

2) Akiyama, N.: Brain and Nerve, 7, 94, 1955.

3) Boenheim, F.: Zschr. Neurol., 60, 10, 1920.

4) Bloor, W. R.: Journ. Biol. Chem., 24, 227, 1916.

5) Bolsi, D.: Zbl. Nervenhk., 42, 288, 1926.

5) Bauer, H. G.: Journ. Clin. Endocrin., 14, 13, 1954.

1) Budge, J.: Arch. Anat. Physiol., 6, 389, 1839.

3) Bechterew, W. V.: Die Funktionen d. Nervencentra., 2, 1909.

7) Ban, T.: Proceeding of Neurological Study, 3, 555, 1959.

j) Bernard, C.: Leçons sur la physiologie et de pathologie du systéme nerveux, 1, 397, 1858 ; refer to Reinhold, Dtsch, Zschr. Nervenhk., 10, 67, 1893.

1) Burgsch, T. et al.: Zschr. Exper. Med., 25, 262, 1921.

2) Dresel, K. et al.: Berl. Kl. Wschr., 58, 739, 1921.

3) Faust, C. et al.: Dtsch. Med. Wschr., 78, 1739, 1953.

4) Gomori, G.: Stain Tech., 25, 81, 1950.

5) Gregerson, M. I.: Journ. Laborat. Clin. Med., 29, 1266, 1944.

6) Georgi, F.: Verh. Ges. Dtsch. Neurol. Psychiatr., Stuttgart, 1951.

7) Hanger, F. M.: Journ. Clin. Invest., 18, 261, 1939.

8) Hampson, J. L.: Journ. Neurophysiol., 12, 37, 1949.

9) Jezler, A.: Zschr. Klin. Med., 114, 739, 1930.

0) Kanai, I.: Elements of Clinical Investigations, 11, 1955.

1) Kumo, T.: Journ. of Experimental Gastroenterology, 17, 415, 1942.

2) Kinoshita, R.: Igakuno Ayumi, 1, 610, 1942.

3) Kojima, K.: Gann, 47, 525, 1956.

4) Katzuki, S.: Proceeding of Neurological Study, 3, 455, 1959.

5) Kurotsu, T.: Shizen, 6, 34, 1951.

6) Lemming: refer to Saito, S., Chiba Igakkai Zasshi, 34, 444, 1958.

7) Lüthy, F.: Dtsch. Zachr. Nervenhk., 123, 101, 1932.

8) McManus, J. F. A.: Nature, 158, 202, 1946.

9) Matsuo, I.: Nippon Naika Zensho, 7, 91, 1951.

0) Miyake, S.: Respiration and Circulation, 5, 93, 1958.

1) Northfield, D. W. C.: Brain, 80, 293, 1957.

2) Nayrac, P.: Rev. Neurol., 31, 151, 1924.

3) Nishii, H.: Osaka Igakkai Zasshi, 11, 605, 1959.

4) Ricker, G.: Zschr. Neurol., 144, 725, 1932.

5) Rössle: refer to Saito, S., Chiba Igakkai Zasshi, 34, 444, 1958.

6) Rosenthal, S. M.: Journ. Amer. Med. Assos., 84, 1122, 1925.

7) Rosa, C. G.: Stain Tech., 25, 265, 1950.

8) Spielmyer, W.: Zschr. Neurol, , 57, 312, 1920.

9) Saito, S.: Chiba Igakkai Zasshi, 34, 444, 1958.

0) Salazarmallin, M. et al.: Amer. Journ. Clin. Path., 20, 39, 1950.

1) Suda, I.: Saishin Igaku, 9, 48, 1953.

2) Usami, K. et al.: Nisshin Igaku, 41, 297, 1954.

3) Vetter, H. et al.: Journ. Clin. Invest., 33, 1594, 1954.

4) Vetter, H. et al.: Journ. Clin. Invest., 35, 825, 1956.

5) Wilson, S. A. K.: Brain, 34, 295, 1912.

6) Yoshino, S.: Journ. of Japanese Internal Medical Society, 44, 121, 1955.

7) Young, W. M.: Journ. Comp. Neurol., 65, 295, 1936.

8) Asai, R.: Nagoya Igakkai Zasshi, 80, 258, 1959. 